\title{
An overview of feed-in tariffs, premiums and tenders to promote electricity from biogas in the EU-28
}

María del P. Pablo-Romero, Antonio Sánchez-Braza, Jesús Salvador-Ponce, Natalia

Sánchez-Labrador

\section{María del P. Pablo-Romero}

Department of Economic Analysis and Political Economy

Faculty of Economics and Business Sciences, University of Seville

Ramón y Cajal 1, 41018 Seville, Spain

Associate Reseacher, Universidad Autónoma de Chile, Chile

Tel.: +34 954557 611. Fax: +34954557629

mpablorom@us.es

Antonio Sánchez-Braza (corresponding author)

Department of Economic Analysis and Political Economy

Faculty of Economics and Business Sciences, University of Seville Ramón y Cajal 1

41018 Seville, Spain

Tel.: +34 954557 529. Fax: +34 954557629

asb@us.es

\section{Jesús Salvador-Ponce}

Department of Economic Analysis and Political Economy

Faculty of Economics and Business Sciences, University of Seville

Ramón y Cajal 1, 41018 Seville, Spain

\section{Natalia Sánchez-Labrador}

Department of Economic Analysis and Political Economy

Faculty of Economics and Business Sciences, University of Seville

Ramón y Cajal 1, 41018 Seville, Spain 


\title{
An overview of feed-in tariffs, premiums and tenders to promote electricity \\ from biogas in the $\mathbf{E U - 2 8}$
}

\begin{abstract}
The EU has assumed objectives for energy sustainability and the fight against climate change. In this regard, the generation of biogas allows contributions to the 2020 established targets. The EU is leader in the production of biogas, representing $60 \%$ of total global production in 2011 . The estimates of the contribution of biogas to electricity generation for 2020 in the EU-28 represent $1.5 \%$ within the total energy mix.

This paper analyzes the measures implemented in the EU-28 to promote biogas, relating them to the country targets established in their National Renewable Energy Action Plans. Currently, 19 countries apply some measure of price and/or amount: 14 use Feed-in Tariffs, 6 Premium Tariffs and 1 uses tenders.

A trend has been observed to reduce public financial support to promote biogas, linked to the reduction of the cost of this technology, and to the attempt to increasingly link it to the markets. However, excessive linking to the market hinders its development, putting the attainment of 2020 targets at risk. Consequently, the Feed-in Tariff or Premium Tariff systems, used in each country, must be designed in agreement with the peculiarities of the development of their markets, to be able to guarantee suitable development.
\end{abstract}

\section{Keywords}

Biogas promotion, Renewable energies, Feed-in tariffs, Premium tariffs, Tenders, National Renewable Energy Action Plans.

\section{Introduction}

The European Renewable Energy Directive 2009/28/EC [1] has created a common framework for the promotion of energy from renewable sources. With this framework, the European Union (EU) assumes energy objectives for energy sustainability and the fight against climate change. Its basic objectives for 2020 are a reduction of $20 \%$ in greenhouse gas emissions, a $20 \%$ energy share coming from renewable sources and the increase of energy efficiency by $20 \%$ [2]. These global objectives for 2020 relate to the Member States that have implemented specific action plans, named as National Renewable Energy Action Plans-(NREAPs), for achieving the targets in line with this directive. Additionally, the Member States have agreed to a new 2030 framework for climate and energy for the period between 2020 and 2030. The 
new targets for 2030 are a $40 \%$ cut in greenhouse gas emissions, a $27 \%$ share of renewable energy consumption and the increase of energy savings by $27 \%$ [3].

The generation of biogas for electricity production allows contributions to the first two energy objectives established by Directive 2009/28/EC. However, the production of biogas also allows additional benefits to be obtained, as this can be produced from the decomposition of organic waste deposited in rubbish dumps, purines and waste from agricultural, industrial and extractive activity, urban waste and other biodegradables. Therefore, it is logical to propose the use of these wastes by means of their conversion into different forms of energy (electricity, heating and cooling and transport), whilst reducing the environmental impact and the emission of methane, a greenhouse gas more detrimental than $\mathrm{CO}_{2}$, emanating from such wastes.

The EU is leader in the production of biogas, representing $60 \%$ of total global production in 2011 [4], with a production in 2013 of almost 13.4 Mtoe. Electricity production is the main biogas energy recovery form. In 2013, output stood at about 4,499 ktoe of final energy [5] (the proxy data for 2014 being equal to 4,627 ktoe [6]), with Germany being one of the countries with greater progress in terms of gross production of electricity from biogas [7]. Heat production output stood at about 2,525 ktoe in 2013 (the proxy value for 2014 being equal to 2,595 ktoe [6]), whereas the use of biogas as biofuel in vehicles is very limited, except in Sweden, Germany and Finland [8]. Therefore, the fundamental use of biogas can be associated with electrical generation. The estimates of the contribution of biogas to electricity generation for 2020 in the EU-28, defined by each country in their NREAPs, are equal to 63.9TWh, which represents $1.5 \%$ within the total energy mix [9].

For the attainment of these objectives and the promotion, in general, of the use of Renewable Energies Sources for Electricity production (RES-E), the countries have been establishing diverse promotional measures that are contemplated in their respective NREAPs. Previous studies have focused on the analysis of the measures used to promote the RES-E in the EU and their effectiveness, such as Cansino et al. [10], Haas et al. [11], Shrimali and Kniefel [12], Batlle et al. [13], Marques and Fuinhas [14], Schmalensee [15], and Del Río and Mir-Artigues [16], among others. Likewise, some other previous studies have focused on the effectiveness of a specific measure, such as Feed-in-Tariffs (FITs). Among the latter can be highlighted the studies by Haas et al. [17], Del Río [18], and Jenner et al. [19]. Additionally, some studies have focused on the measures implemented to promote RES-E derived from a specific technology, such as photovoltaic [20-22], wind [23] or biomass [24]. 
Following the previous studies, the aim of this paper is to analyze the price and quantity measures implemented in the EU-28 to promote biogas (Feed-in Tariffs [FITs], Premium Tariffs [FIPs], and tenders), relating them to the country targets established in their respective NREAPs. This analysis is interesting because, although biogas is not the main contributor to biomass electricity, very good progress is expected. Recent developments increased the share of biogas above the expected 2015 levels, being 35\% above the level forecast for 2012 [25].

Additionally, focusing on regulatory measures is interesting because they are implemented in the long term, 15-20 years, and usually through a Power Purchase Agreement (PPA), allowing profitability guarantees to be offered to the investment projects. Thus, according to Resch et al. [26], the possible combination of the three regulatory measures mentioned previously, increases the confidence of investors to undertake RES-E projects. Other support mechanisms, such as subsidies or low-interest loans, among others, can be classified as complementary or exceptional support since, at the time of undertaking the project, no future guarantees are given about its profitability [27].

In order to carry out this analysis, the main sources that have been taken into account, but which are far from exhaustive, are the information included in the RES-Legal database [28], the Global Renewable Energy Policies and Measures from the IEA database [29], the NREAPs [30], EurObserv'ER [5, 31-33] and CEER report [34].

This work is structured as follows. Section 2 analyzes the present situation of biogas electricity generation in the EU-28 and their targets for 2015 and 2020. Section 3 covers the regulation policy measures implemented in the EU-28 countries related to this energy. Section 4 discusses the effects of these policies. Finally, the conclusions are presented.

\section{Present situation and objectives}

Figure 1 shows the electricity from renewable sources targets in the EU-28 countries in 2010, 2015 and 2020. The differences between countries should be highlighted, with electricity from renewable sources being especially relevant in Germany, Spain, France, U.K., Sweden, Italy and Austria.

\section{[Fig. 1]}


The generation of electricity through renewable energy has been established using various sources, one of which is biogas. Figure 2 shows the contribution of each renewable energy source to electricity production in the EU-28 in 2012. In that year, the percentage of electrical energy obtained by biogas was $6 \%$, in agreement with the data collected from the NREAPs. In addition to its relative importance, it is also possible to emphasize its growth, because the contribution of biogas to electricity generation through renewable energies has risen to $45 \%$ in only two years. It is notable that at the end of 2013, the electrical energy coming from biogas plants in Europe rose to 52,300 GWh and the number of power stations reached 1,611 plants [5].

\section{[Fig. 2]}

In the EU-28, there are three main biogas production sources. Firstly, biogas can be obtained by a passive mechanization process, directly recovered from landfills. Secondly, biogas may also be generated from urban wastewater and industrial effluent treatment plants (sewage sludge gas). Finally, it can be produced by other plants: Purpose-designed energy conversion mechanization plants and the multi-product mechanization plants. The first, as stated in EurObserv'ER [35], comprise mechanization units on farms that convert slurry, crop residues and energy crops. Additionally, they include food-processing industry mechanization plants and solid waste mechanization plants. The second include those that can convert different types of organic waste.

Figure 3 shows the primary energy production of biogas from these three main sources in the EU-28, in 2010 and 2013. As shown in this Figure, the main biogas production comes from the third above-mentioned source, with a share of $69 \%$ of total biogas energy production in 2013. Landfill biogas represents $22 \%$ and the rest comes from sewage sludge plants. These percentages vary from 2010. The landfill biogas percentage has been reduced by four points, increasing the biogas generated by other plants. Nevertheless, this four-percentage point decrease is not due to a landfill energy production reduction, but to a lower growth than that achieved by the other two main sources. Thus, while the average growth rate of primary biogas production was equal to $23.01 \%$ during this period, landfill biogas was only $3.2 \%$. The other main sources of biogas growth rate were sewage sludge gas and other biogas, at $17.7 \%$ and $31.73 \%$ respectively.

\section{[Fig. 3]}


Figure 4 shows the primary energy production of biogas by EU-28 countries and sources in 2013. Three countries are the main biogas producers in the EU-28: Germany (50\%), U.K. $(14 \%)$ and Italy (14\%). Nevertheless, differences are observed in biogas sources. The U.K. is highlighted in landfill biogas production, representing 53\% of total production. Italy and France are other relevant producers, with $14 \%$ and $10 \%$ participation. Sewage sludge biogas is mainly produced by Germany (31\%) and the U.K. (23\%). Finally, other biogas production is mostly concentrated in Germany $(67 \%)$ and in Italy (15\%).

[Fig. 4]

Table 1 shows the production and evolution of the electricity generated from biogas in the EU-28 countries. Column 2 shows production in 2010 and 2013. Column 3 shows the growth between previous years, in absolute and relative terms. The last row in Column 3 shows that electricity generated from biogas increased by $20,467.20 \mathrm{GWh}$ in the EU-28, the growth rate being equal to $64 \%$. Column 4 shows the ranking in production and growth terms. Five countries are highlighted for their high 2013 production: Germany, Italy, the U.K., the Czech Republic and France. Graph A in Figure 5 shows that Germany, Italy and the U.K. generated $56 \%, 14 \%$ and $11 \%$ of total biogas electricity, respectively. The countries with the smallest biogas electricity production, in 2013, were Bulgaria, Malta and Sweden, the latter, despite its high RES-E target. In terms of growth, Germany, Italy, the Czech Republic and France are the foremost countries in the EU ranking, with Poland now added to this list. It should be pointed out that some countries have negative growth rates: Austria, Bulgaria, Denmark, Ireland and the Netherlands.

\section{[Table 1 and Fig. 5]}

Table 2 shows the targets for electricity generated from biogas that the EU-28 countries have established for 2010, 2015 and 2020, in order to reach their 2020 RES-E target. It can be observed that there are great differences between country targets, which cannot always be justified by differences between country sizes. Additionally, it can also be observed that targets tend to grow through time, but with different positive trends. It is also worth noting that some countries have constant targets, such as Ireland and Sweden, and some have decreasing values, such as the U.K. Graph B in Figure 5 shows the countries with the highest targets for 2020. Germany's biogas electricity target represents 37\% of the EU-28 target. Italy 
and the U.K. follow in importance, with $10 \%$ and $9 \%$ values respectively. The targets of ten countries represent $90 \%$ of the total EU-28 target.

Table 2 also shows the level of compliance of countries' targets, as a percentage of the biogas electricity generation related to the target value. Three levels have been considered. First, the 2010 biogas electricity generation with respect to the 2010 target. Second, the 2013 biogas electricity generation with respect to the 2015 target, Finally, the 2013 biogas electricity generation with respect to the 2020 target. The year 2013 was chosen as it is the last year for which data are available. Numbers in bold have been used to show the countries that have surpassed their respective target. In 2010, only fifteen countries reached their targets, although the EU-28 did reach them overall. Among the countries which have not done so, only 5 were near the target value, Malta did not generate any biogas GWh and Romania was far removed from its target, with only a 5.6\% level of compliance. In 2013, seven countries had already reached the 2015 targets: Austria, the Czech Republic, Finland, Germany, Italy, Latvia and Portugal. Likewise, Hungary, Poland and the U.K. were very close to their targets. However, several 2010 compliant countries are now far removed from their 2015 targets. This is the case with Denmark, Greece, Luxemburg and the Netherlands. Nevertheless, the EU-28 target has been compliant overall. Finally, it is worth remarking that five countries have also reached their 2020 targets: Austria, Germany, Italy, Portugal and the U.K. However, the U.K. has reached it because the target was reduced for 2015 and 2020, and Portugal has very low targets. Globally, in 2013, the level of compliance with the 2020 target was equal to $82.81 \%$, so it is predicted that the 2020 target will be fulfilled.

\section{[Table 2]}

\section{Regulatory measures for the promotion of biogas}

There are several instruments of energy policy to impel the use of RES-E. For the specific case of biogas, three types of regulatory measures are highlighted which affect prices and quantity. The FITs and FIPs stand out among the price regulation measures, whereas tenders are an example of quantity regulation measures. Other support mechanisms can occasionally be applied, such as subsidies or low-interest loans, although they can be considered more as complementary or exceptional support. 


\subsection{Feed-in tariffs (FITs)}

Feed-in tariffs (FITs) are the minimum prices guaranteed by the national governments for each $\mathrm{kW}$ generated, injected into the network or used for self-consumption. The primary policy objective of the FITs is to offer guaranteed fixed prices for a certain period of time for RES-E. The FITs include both the price of the electricity and the additional support, given as a unique joint payment.

The factors that can be taken into account by governments for the determination of the FIT prices are very diverse. Factors such as the renewable energy source and its cost, the installed capacity of the plant, the energy generated, the location, the period of emission of electrical energy to the network, etc. [36-37], give rise to divergences between the different countries that apply the FITs. The guaranteed price is established for a broad period of time, approximately 15 to 20 years, so that the producers affected by this measure have a clear orientation on the repayment that they are going to receive throughout the life of the project.

Thus, the stability present in the FIT, due to the fore-knowledge of the fixed price throughout the evolution of the project, gives an immunity to possible price volatility, and is one of the greater attractions of this system of promotion. Nevertheless, the difficulty for governments in establishing a sustainable and profitable level of FIT for the promotion of the different types of RES-E over a long period, can become one of its main handicaps.

Table 3 shows the fourteen EU-28 countries that apply FIT policies. In addition, some of the basic characteristics of their system are included.

\section{[Table 3]}

In the case of Croatia, to receive this support until the end of 2015, it was necessary to acquire the condition of "qualified producer" and to sign the contract of provision with the Croatian Energy Market Operator (HROTE). A new Renewable Energies Act has provisions to convert this FIT system into a Premium Tariff (FIP) support scheme. However, this new scheme is not as yet adopted [28]. Likewise, France also foresees reshaping its support schemes. The new system will combine FITs and an additional remuneration. Nevertheless, the enforcement decree is not yet published, therefore, the current regulations apply. In addition, until 2014, the Czech Republic had implemented both FITs and FIPs, nevertheless, at the beginning of that year the support linked to renewable energy was suspended due to the high costs [38]. 
The second column of Table 3 shows whether the country has progressive fixed price reduction systems, whereby the fixed prices diminish throughout the considered period. The main reason for this mechanism is to provide an incentive for the reduction of electricity generation costs and greater speed in the development of renewable energies during the first years [39]. Although most of the countries resort to this initiative, countries such as Croatia, Ireland and Bulgaria do not apply this regressive mechanism, generally adapting their tariffs to the evolution of prices. In addition, the case of Portugal should be highlighted, as it fixes FITs at two levels for micro-production and mini-production units, presenting a higher tariff for the first eight years of activity and a lower tariff for the following years.

However, it is not possible to define a general pattern of adjustment of the tariff to the rate of inflation, due to the latent divergences both in the methodology used, and in the jurisdictions of each country. Therefore, some countries adapt their FITs through a pre-established formula that readjusts the whole of the tariff, whereas others make a partial adjustment with a percentage on this tariff. In addition, this process can be undertaken throughout a different timescale (monthly, quarterly, annually, etc.). Thus, for example, Ireland adjusts its FIT to $100 \%$, which protects the real value of the income of the project, whereas Germany makes the calculation of the tariff, assuming an average inflation of $2 \%$ [28]. Thus, a quarterly $0.5 \%$ reduction is applied. Nevertheless, for landfill gas and sewage gas the annual reduction rate is $1.5 \%$. For other forms of biomass, Greece adjusts it to $50 \%$ of the prices index [33], and France applies an adjustment that oscillates between $40-100 \%$ of the base price of electricity, based on the type of technology [37]. In Slovenia, FITs are also adjusted to the evolution of the prices, but the tariff is guaranteed for at least three years. Likewise, FITs will not be reduced if they are used as measures to achieve the required emission limits. Finally, in the U.K., a "contingent degression" system is applied. The degression rates are adjusted depending on the deployment level. If the deployment level reaches the biogas cap, the tariff will be reduced by $10 \%$. Currently, the cap is equal to $5 \mathrm{MW}$ [28].

The third column of Table 3 shows the period that the FITs are applied for each country, and it can be seen that all the countries guarantee their FITs for between 10 and 20 years, although a duration of at least 15 years is recommended to offer a low risk to investors [26].

Finally, the fourth column of Table 3 shows the main price determining factors in each country, based on their established FIT system, while the fifth column shows the current FIT amounts. Additionally, Figure 6 shows the price ranges that the biogas plant operators can 
obtain if they opt for the FIT system, and demonstrates the diversity and variability of these guaranteed tariffs based on the country.

\section{[Fig. 6]}

This Figure shows that Germany displays the highest guaranteed prices, although it is also the country with the widest range, and also one of the countries that presents the lowest minimum payment, behind Hungary, Bulgaria and Austria, which present the lowest guaranteed minimum prices.

The guaranteed prices will vary depending on different factors, with the two main factors generally being the installed capacity or the size of the plant, and the technology of the plant or origin of the biogas. With respect to the first, higher prices are offered to the small biogas plants, with the exception of Luxembourg, which increases its FIT amount for greater capacities. With respect to the second, Hahns and Jentsch [39] indicate, for example, that electricity generated from agricultural biogas has been having higher prices than the gas originating from waste waters or rubbish dumps, for the case of Germany, Bulgaria, Austria and Greece. Currently, as shown in the last column in Table 3, generally the highest FITs are applied for electricity generated by biomass plants and anaerobic digestion plants, while the lowest tariffs are applied for biogas electricity generated from landfill plants.

In the case of France, the established tariff is also related to energy efficiency. In this way the operators of the plants can receive a bonus on the FIT prices which will depend on the amount of exported electricity, and the degree of support for the attainment of the set energy objectives. Thus, there is an incentive of $0.04 € / \mathrm{kWh}$ for those which reach an energy efficiency of at least $70 \%$ [28]. In addition, there is a second bonus for biogas obtained from the treatment of waste water, the amount of which can reach up to $0.026 € / \mathrm{kWh}$ for facilities up to 1 MW capacity, whenever the mechanization plant obtains a proportion of the same, greater or equal to $60 \%$ [33]. Likewise, farmers may obtain a revaluated tariff with the aim of improving their profitability if the producer is the holder of a purchase contract and has filed an identification application.

In the case of Ireland, it is also possible to emphasize the positive valuation when designating the amount of its FITs when dealing with Combined Heat and Power (CHP) plants. Unlike conventional electricity plants, CHP plants capture the heat that in other cases is expelled in the process of obtaining electricity, considering it as lost energy. The conventional electrical 
plants will also have access to the FIT system although with lower tariff ranges. Likewise, the FITs depend on the plant capacity. Thus, plants with a capacity below $500 \mathrm{~kW}$ have higher tariffs. Nevertheless, currently, the Irish government is working on a new scheme that will be available from 2017. The new scheme will be subject to the new procedures on public energy support approved by the European Commission in 2014 [40], which pursue a move to marketbased support [41].

The quantity of the bonus in Greece and Slovenia varies based on the receipt of some extra income, that is to say, whether the biogas plant has received some governmental support such as subsidies, or has adhered to some funding program financed by the EU, etc. In Greece, the support must exceed $20 \%$ of the total cost of investment to be considered relevant. Likewise, currently, in Slovenia, only operators with capacities below $500 \mathrm{~kW}$ can receive FITs [42].

In the case of Hungary, the FITs are established based on the electricity consumption, establishing three tariff sections: the peak period, valley period and deep-valley period. The hours associated with each section can change on holidays, depend on the season of the year, etc. These tariffs also depend on the capacity of the plant: below $20 \mathrm{MW}$, between 20 and 50 MW and above $50 \mathrm{MW}$.

Finally, Lithuania and Portugal present a variant in the determination of the FITs, as they base it on the results obtained in rounds of tenders. Thus, in Lithuania the FIT prices are fixed quarterly, taking the price of electricity in the three months prior to the call for tenders as reference. This mechanism fixes guaranteed tariffs and maximum FITs for the subsequent tender procedures. Access to the tender rounds is limited to plants with an installed capacity of greater than $10 \mathrm{~kW}$. A support known as surplus electricity is awarded to plants with less capacity, which consists of determining a minimum price, after which the government pays up to $50 \%$ of the electricity generated from renewable energy sources for one year. In the case of Portugal, the plants classified as small production units also use this mechanism to determine their tariff. The micro-production and mini-production plants will have their corresponding FIT reference tariff. The tariff is calculated through a bidding system in which producers offer discounts of a benchmark tariff set by the government. The final tariff will be the highest amount resulting from the highest discount offered [28]. 


\subsection{Premium tariffs (FIPs)}

The Premium tariffs or feed-in Premiums (FIPs) is a system of support for RES-E that establishes a premium on the existing market electricity price. Thus, it generates two sources of income for the producers: one with the sale of energy in the electrical market and the other with the receipt of the premium [18-19]. In a similar way to the FITs, the premium differs based on the criteria applied in each country (energy source or technology used, size of the plant, electricity generation costs, etc.).

The FIPs can be classified as fixed or sliding premiums. In fixed premiums, applied in the case of biogas by Denmark, Italy and Slovenia, a constant amount is added to the existing market price. However, in the case of elevated prices in the market, this model can grant an excess of income with the supplement of the premium. In the same way, the possible fall of the prices does not assure minimum income to the producers, which could drive away potential investors. For that reason, some countries resort to the system of sliding premiums with the intention of controlling how price fluctuations fix the limits of the premium. In the case of biogas, this modality is applied by Germany, Finland and the Netherlands, which apply a variant called the "spot market gap model" consisting of guaranteeing a minimum level of payment, granting a premium equal to the difference between a fixed minimum payment and the price of the electricity. In the case that the market electricity price is higher than the guaranteed minimum, the premium is zero, with the producer receiving only the market price $[38,43]$.

Table 4 shows the countries of the EU-28 that apply FIP policies, including some of the basic characteristics of their systems of application.

[Table 4]

The divergence of criteria between countries in the manner of estimating quantity, duration, restrictions, extra incentives, legal requirements, etc., makes it impossible to determine a common pattern between the countries in the determination of the FIPs, giving rise to greater diversity and variability in the quantities for each country. The range of the quantities of FIPs for the operators of the biogas plants is shown in Figure 7.

[Fig. 7] 
As Figure 7 shows, Germany again presents the highest quantities and is also the country with the widest range, together with Italy. As with the FITs, the installed capacity or size of plant, and the technology or origin of the biogas, are the two main factors for the determination of these quantities. For example in Germany, biogas electricity from biomass has the highest applied FIPs while in Italy, the highest FIPs are applied for biogas from products of biological origin. Nevertheless, in the case of the FIPs, a greater number of specificities and differentiating characteristics are presented for each country. Current FIP values are shown in the last column in Table 4.

Germany and Slovenia enable access to one of the two price measures, FITs or FIPs, based on the capacity of the plants. In the German case, the biogas plants with capacity greater than $750 \mathrm{~kW}$ will only be able to opt for FIPs. In Slovenia, a new market premium scheme has recently been introduced for operators above $500 \mathrm{~kW}$. Accordingly, operators of these installations will receive their support in the form of a premium paid on top of the market price, while operators below $500 \mathrm{~kW}$ may continue to receive a FIT [42].

In the case of Italy, its FIP system offers the possibility for plants with power lower than 1 MW to qualify for a special tariff, called the all-encompassing tariff, which allows a higher guaranteed minimum, although the maximum, and the duration of the concession, are the same as for the modality of traditional FIPs [44]. The FIP value is obtained as the sum of a tariff for a given plant category, plus other support elements (incentives for greenhouse gas reductions in the case of supply-chain-biomass-fueled plants, for compliance with the atmospheric emission requirements, for high-efficiency cogeneration and other additional bonuses), minus the hourly energy market price for a given price zone. Nevertheless, the premium is equal to the sum of the tariff and other support elements, if market prices are negative $[34,45]$.

Denmark's FIP system is based on variable bonuses, which are added to the income from the sale of electricity in the market. Two bonus classes exist: the maximum bonus, which, linked to the market price, cannot exceed a certain amount fixed by law, and the guaranteed bonus, the total amount of which has no pre-fixed limit [46]. For electricity generated by biogas plants, produced by using exclusively biomass, the maximum bonus in 2016 is $11 € \mathrm{ct}$. per $\mathrm{kWh}$. Additionally, guaranteed premiums of $3 € \mathrm{ct}$. and $1 € \mathrm{ct}$. per $\mathrm{kWh}$ are also paid. The first is reduced or increased each year if the price of natural gas exceeds or falls below a basic level. The second is reduced annually until 2020, when it will disappear. For electricity generated 
by biogas plants produced by using biomass and other fuels, an FIP equal to $6 € c$ ct. per kWh is paid for the portion of the electricity generated by biogas. Additionally, guaranteed premiums of $3 € c t$. and $1 € \mathrm{ct}$. per $\mathrm{kWh}$ are also paid for the part of the electricity generated by using biogas [32].

Something similar is found in the German and Finnish systems. In Finland, the FIP tariff is equal to the difference between the fixed target price and the reference market price. The latter is calculated as an average of the hourly prices over the previous three months [34]. Nevertheless, if the reference market price is below 30€, the FIP will be equal to the difference between the fixed target price and $30 €$. Additionally, Finland has heat bonuses dedicated to biogas plants that produce electricity and heat, and have an energy efficiency of at least $50 \%$, or even $75 \%$ if the capacity of the generators is greater than $1 \mathrm{MW}$. In a similar manner, the FIP tariff in Germany is equal to the difference between the fixed reference value and the average specific market price, which is calculated every month. Germany grants an extra premium, termed the management premium, destined to cover the additional expenses of the plant (personnel, costs of management, infrastructure, etc.), differentiating its amount depending on the renewable energy source. It also offers a second additional premium for biogas producers if they increase their installed capacity to produce more electricity, with the intention of improving their adaptation to market demands.

Therefore, the capacity of the plant and origin of the biogas (biodegradable waste, gases from rubbish dumps, slurry fermentation, etc.) are determinants in fixing the premium amounts in the German, Dutch and Slovenian systems. In the case of the latter, greater flexibility has also been offered for CHP plants opting for the FIP system, extending the range of capacity allowed from $1 \mathrm{MW}$ to $20 \mathrm{MW}$. Recently, operators of systems above $500 \mathrm{~kW}$ offer the produced energy on the market and receive a premium on top of the market price. Slovenia has introduced a two-round tender process to ensure support goes to the best value projects [47].

The Netherlands follow a sliding Premium system determined by tender, popularly called "SDE+", to establish their FIPs. Thus, based on the origin of the biogas, the government usually establishes five or six annual rounds of tenders, so that the amount of the premium depends on the round in question, normally increasing with the stage of the round, which is why many operators wait until the latter rounds to obtain the highest premium. Nevertheless, there is the risk that, as the year advances, the SDE+ system will close due to budgetary 
constraints, with no support being granted to the remaining bidders [43]. Thus, there is an incentive for low-cost bids to be introduced in the first calls, thereby explaining their "first come, first served" designation [48].

Finally, Column 3 of Table 4 shows the duration of the FIP systems for each country. Italy and Germany, two of the large producers of biogas in the EU, are those that offer a longer duration, 20 years. In the case of Denmark, it has various terms and conditions, which depend on the technology used and the commissioning date of the plant.

\subsection{Tenders}

With respect to the price measures, tenders are an integral part of the RES-E support mechanisms that are linked to the amount. In this system, the governments and regulating authorities request bids for the supply of electrical energy, by means of a specific technology, with the purpose of receiving an energy service at a competitive price and of developing that particular technology, in this case, the RES-E. The process is carried out by means of bidding between the participants, once a fixed amount of capacity from renewable energy sources in the electricity network of the country has been established. The bids are fixed for a certain capacity, technology and location. The government is limited by qualitative and quantitative criteria when selecting the winning bid. However, in practice, it is usually the less expensive bid that is chosen, normally selecting one beneficiary per location [49].

An advantage of this system is its effectiveness in promoting price competition between the different operators and technologies, which reveals the true cost of electricity generation from renewable resources. In addition, most tenders are linked to supply contracts (Power Purchase Agreement [PPA]) executed over a period of 15 to 20 years, according to the prices established in the bid, giving security to the investment [49]. On the contrary, the main disadvantages are the sporadic and intermittent manner in which the tender rounds are made, and the possible collusive behavior of the participants, by jointly raising the price of the energy and not revealing its true cost [50].

In the scope of the EU-28, Italy is the only country that establishes tenders for the case of biogas. The system of incentives is based on the monthly concession of a bonus for the plant operator. This incentive is calculated by adding the premiums or bonuses, that have been granted to the plant, to the tariff bases determined for the energy sources (which includes a 
predicted progressive reduction of $2 \%$ per annum), so that the price per hour in the electricity market is reduced. The range of variation of this incentive oscillates between $0.085 €$ and $0.122 €$ per kWh [28].

Although only Italy uses tenders as a measure for biogas promotion, there are countries that support this system for the determination of their FIT or FIP amounts [51]. Such is the case, as already commented, of Lithuania and Portugal for FITs, and of the Netherlands and Slovenia for FIPs. Thus, the introduction of tenders as a support mechanism represents a more competitive and economically attractive method of fixing the remuneration levels [38].

\section{Discussion}

Table 5 provides a general view of the price and quantity measures implemented in the EU-28 to promote the use of biogas in electricity generation. Additionally, Table 5 shows the degree of fulfillment of the targets set for 2020, as mentioned in Table 2, and the growth of electricity production from biogas between 2010 and 2013, shown in Table 1.

Firstly, it can be pointed out that nine countries of the EU-28 do not apply any of these support systems to promote biogas. Table 5 shows that these countries generally have levels of fulfillment of the 2020 target and very low absolute growth. Two exceptions can be mentioned: the Czech Republic, which used FIT and FIP systems until 2014, when the system was eliminated because of the high costs they were generating, and Poland, whose absolute growth in the period places it in fourth position, in agreement with Table 1. Support schemes regarding RES-E from biogas in Poland have been based on the so-called certificates of origin.

Those countries with greater growth in the use of biogas for electricity generation have established support mechanisms based on price or quantities. Germany, Italy and the U.K. have systems with very long term guarantees of 20 years duration, which make investments more attractive. Therefore, it can be considered that the application of the support mechanisms is in direct correlation with the development of the biogas industry, which is also reinforced by the fact that all the countries that have already fulfilled the 2020 target, have established some, or several, support systems. Thus, in agreement with the working document of the European Commission [52], it is possible to say that, although there are reports [49] which indicate that some technologies related to biogas can be considered mature and 
competitive in the market, in most cases, electricity generation from biogas requires public financial support. Therefore, the absence of support mechanisms is translated into poor growth of electricity generation from biogas.

Table 5 also shows that there are different combinations when choosing the type of system applied by the countries. It is possible to say that a trend is observed towards using systems different from the more traditional FIT system. Thus, it is observed how several countries have adopted FIPs and even tenders. It is also observed that, in agreement with Couture et al., [53], these policies are beginning to be used in combination, in order to meet different goals. On the other hand, it can also be observed how the countries have begun to apply varied designs of FITs to reach diverse objectives, such as favoring smaller project sizes that can help drive significant investment, as in France, or higher end-use efficiency as in France, Greece and Luxemburg. Likewise, it should be noted that policies are being implemented taking into account market evolution. As stated in Couture et al. [53], countries' policies are mostly designed to maintain a high degree of revenue security while simultaneously requiring producers to interact with wholesale spot markets, for example, by using some types of FIP or relating FITs to tenders. It can be noted that the different designs of these measures in each country can help the implemented policy to have greater success, because they allow better adaptation to the circumstances of each particular market.

Some considerations can also be noted with respect to the countries with greater fulfillment of their targets. Austrian biogas plant operators are facing local caps and have a growth practically equal to zero. Germany, a country that has also already fulfilled its 2020 target, continues to maintain its FIT system, although recently it has been revised by the new Renewable Energy Sources Act 2014, which provides for a revised system of fixed feed-in tariffs and marketing premiums. One of the objectives of this Act is to reduce financial costs by slowing the growth of the most expensive electricity generating sectors, such as biogas. In this regard, a set of measures have been articulated which are directed to a better integration of biogas into the electricity market. On the other hand, Italy, a country that has also fulfilled its 2020 targets, has reduced its incentives, due mainly, as Maggioni [45] affirms, to the fact "that renewable sources have already achieved a sensible development in the last years", and, to the criteria of production costs. Contrary to this trend, FIT for electricity produced by cogeneration installations running on biogas will be raised for both new and existing installations. The increase will be between 10 and $20 \%$, considering contracts of 20 years to be necessary to give a better return on investment [54]. From the previous considerations, it 
can be seen that there is a trend in recent years to reduce public support linked to cost reduction. Nevertheless, this trend can increase the risk for the investors and thereby reduce the growth of the sector. As stated in Couture et al. [53], policymakers need to weigh the benefits of including biogas producers in markets against the potential negative impacts on sector development.

Finally, it can be highlighted that the countries, when designing their FIT systems, are considering the resources used for biogas generation. For example, the premium for using energy crops and manure has been withdrawn in Germany with the aim of encouraging the use of organic and farming waste. This last limitation, which is in line with the objectives of the EU-28, may have a negative impact on the biogas sector's growth. Thus, Thrän et al. [55] report that about $80 \%$ of biomass resources in biogas plants resulted solely from energy crops in Germany in 2013. Likewise, Italy has also begun to give preference to the use of byproducts and farming waste over energy crops. In parallel, the U.K. has plans to establish regulatory control on the use of crops, whilst it is in discussion on cuts to the applied systems [56]. The present political discussions limiting the raw material base can also hinder the growth of this energy. The working document of the European Commission [52] referring to biomass, considered that bioenergy installations should achieve GHG savings of at least $70 \%$, compared to the fossil fuel comparators. This target is hardly attainable when certain technologies are used, among them those technologies that use maize silage or open codigestion of a mixture composed of $70 \%$ manure and $30 \%$ maize silage.

The establishment of new requirements of production, and the trend to increasingly orient it to market prices, can endanger the present development of the biogas sector. Nevertheless, the good development of the sector has a fundamental advantage over other types of renewable energies. As a flexible system, it may fill the valleys of wind and sun energies, according to Bourguignon [57].

\section{[Table 5]}




\section{Conclusions and policy implications}

Recently, RES-E from biogas has increased more than initially expected in the EU-28. In the period 2010-2013, electricity generated from biogas grew by $20467.20 \mathrm{GWh}$, representing a growth rate of $64 \%$. This notable growth has meant that EU-28 targets for 2015 were fulfilled in 2013. Five countries are highlighted for their high 2013 production (Germany, Italy, the U.K., the Czech Republic and France), generating nearly 90\% of the total. This important growth in the EU-28 has also seen the first RES-E from biogas production. It is also worth noting, that in 2016, the U.K. decided to exit from the EU. This fact will affect the EU global production in future, as the U.K. is one of the largest producers of biogas in Europe.

Currently, 19 countries of the EU-28 apply some price and/or amount measures to promote the use of biogas and of those countries, 14 use FITs, 6 FIPs and 1 uses tenders. The countries that do not use any of these measures generally have poor levels of biogas growth, and are far from fulfilling their 2020 targets. Additionally, the countries with greater growth of biogas for electricity use and greater levels of fulfillment of their targets (Austria, Germany, Italy, and the U.K.), use some of these systems. It is only possible to indicate the exceptional position of the Czech Republic, which has high growth and an elevated level of fulfillment of its targets and does not currently apply these measures, due to its need to eliminate them for reason of high costs.

In relation to the form in which FITs are applied, it is observed that the majority apply degressive systems (except Croatia, the U.K., Ireland and Bulgaria), although the methodologies applied in each country are different, and they are made with different regularities. The period of application of the FITs also varies between countries, although it is mainly positioned between 15-20 years, with two exceptions: Lithuania and Croatia. Finally, it is possible to say that the amount of the FITs depends on certain factors in each country, emphasizing the installed capacity and the technology of the plant or the origin of the biogas. In general, higher prices are offered for the energy coming from small biogas plants and generated from agricultural biogas. In France, the established tariff is also related to the energy efficiency, in Greece and Slovenia it varies based on the receipt of some extra income (for example, subsidies), and in Hungary they are established based on electricity consumption. In addition, Lithuania and Portugal determine the value of the FITs based on the results obtained during the rounds of tenders. Regarding the amount, Germany displays the 
highest guaranteed prices, and is also one of those that offer the lowest guaranteed prices, behind Hungary, Bulgaria and Austria.

In the EU-28, two different FIP systems are applied. Denmark, Italy and Finland apply a fixed premium, whereas Germany, Slovenia and the Netherlands apply a sliding premium modality, called the "spot market gap model". There is no common pattern in the determination of the FIPs. The installed capacity and the technology or the origin of the biogas are also the two main factors for the determination of these amounts. Nevertheless, there is a greater number of differentiating characteristics for each country. Regarding the duration, it oscillates between 12 and 20 years. Italy and Germany are those that offer a longer duration. The higher amounts are offered in Germany, although they have a wider range variation, together with Italy.

Italy is the only country of the EU-28 that establishes tenders for biogas. This system is based on the concession of a bonus for the operator of the plant every month. However, other countries of the EU-28 use tenders to determine the amounts of their FIT (Lithuania and Portugal) and FIP (the Netherlands and Slovenia) tariffs.

In general, it is observed that there is a trend to reduce public financial support for the promotion of the RES-E from biogas, linked to the reduction of the cost of generation of electricity with this technology, and to the attempt to increasingly link it to the markets. However, excessive linking to the market hinders its development, at least in some countries, putting the attainment of 2020 targets at risk, as it cannot be considered that the market is sufficiently mature. Therefore, the FIT or FIP systems used in each country must be designed in agreement with their peculiarities and the level of development of their own markets, to be able to guarantee suitable development.

In addition, there is a trend seen in the design to limit support for the generation of biogas where certain materials are used for its generation, with the purpose of increasing GHG savings. This endangers the use of some technologies, such as those that use maize silage or open co-digestion of a mixture composed of $70 \%$ manure and $30 \%$ maize silage. Thus, it may be convenient to establish long periods of adaptation, in order that the technologies can evolve sufficiently to reach higher levels of GHG savings. The contrary could result in a good part of the currently used technologies being left without support, hindering the development of these renewable energies. 


\section{Acknowledgements}

The first and third authors wish to acknowledge the financial support received from the ECO2014-56399-R Project of the Spanish Ministry of Economy and Competitiveness, the Cátedra de la Economía de la Energía y del Medio Ambiente (Chair of Energy and Environmental Economics) of the University of Seville, the Fundació Roger Torné, and from the SEJ-132 Research Group.

\section{References}

[1] European Parliament and the Council. Directive 2009/28/EC of the European Parliament and of the Council of 23 April 2009 on the promotion of the use of energy from renewable sources and amending and subsequently repealing Directives 2001/77/EC and 2003/30/EC. Official Journal of the European Union L 140; 2009: 16-62. Available at: http://eur-lex.europa.eu/legal-content/EN/TXT/PDF/?uri=CELEX:32009L0028\&from=EN [accessed 10.11.16]

[2] European Commission. Europe 2020: A strategy for smart, sustainable and inclusive growth. Communication from the Commission to the European Council. European Commission, Brussels, 3.3.2010 COM(2010) 2020 final; 2010. Available at: http://eur-lex.europa.eu/legal-content/EN/TXT/PDF/?uri=CELEX:52010DC2020\&from=ES [accessed 10.11.16]

[3] European Commission. A policy framework for climate and energy in the period from 2020 to 2030. Communication from the Commission to the European Parliament, the Council, the European Economic and Social Committee and the Committee of the Regions. European Commission, Brussels, 22.1.2014 COM(2014) 15 final; 2014. Available at: http://eur-lex.europa.eu/legal-content/EN/TXT/PDF/?uri=CELEX:52014DC0015\&from=en [accessed 10.11.16]

[4] Raboni M, Urbini G. Production and use of biogas in Europe: A survey of current status and perspectives. Revista Ambiente \& Água 2014; 9: 191-202.

[5] EurObserv'ER. Biogas barometer; 2014. Available at: http://www.eurobserv-er.org/biogasbarometer-2014/ [accessed 10.11.16]

[6] EEA. Renewable energy in Europe 2016. Recent growth and knock-on effects. EEA report 4/2016. Copenhagen: European Environment Agency; 2016. Available at: http://www.eea.europa.eu/publications/renewable-energy-in-europe-2016 [accessed 10.11.16]

[7] Trávníček P, Kotek L. Risks associated with the production of biogas in Europe. Process Safety Progress 2015; 34: 172-8.

[8] EurObserv'ER. Biofuels barometer; 2014. Available at: http://www.eurobserv-er.org/biofuelsbarometer-2014/ [accessed 10.11.16]

[9] EurObserv'ER. The state of renewable energies in Europe; 2014. Available at: http://www.energies-renouvelables.org/observ-er/html/quest_bilan_14.html[accessed 10.11.16] 
[10] Cansino JM, Pablo-Romero MP, Román R, Yñiguez R. Tax incentives to promote green electricity: An overview of EU-27 countries. Energy Policy 2010; 38: 6000-8.

[11] Haas R, Panzer C, Resch G, Ragwitz M, Reece G, Held A. A historical review of promotion strategies for electricity from renewable energy sources in EU countries. Renewable and Sustainable Energy Reviews 2011; 15: 1003-34.

[12] Shrimali G, Kniefel J. Are government policies effective in promoting deployment of renewable electricity resources? Energy Policy 2011; 39: 4726-41.

[13] Batlle C, Pérez-Arriaga IJ, Zambrano-Barragán P. Regulatory design for RES-E support mechanisms: Learning curves, market structure, and burden-sharing. Energy Policy 2012; 41: 212-20.

[14] Marques AC, Fuinhas JA. Are public policies towards renewables successful? Evidence from European countries. Renewable Energy 2012; 44: 109-18.

[15] Schmalensee R. Evaluating policies to increase electricity generation from renewable energy. Review of Environmental Economics and Policy 2012; 6: 45-64.

[16] Del Río P, Mir-Artigues P. Combinations of support instruments for renewable electricity in Europe: A review. Renewable and Sustainable Energy Reviews 2014; 40: 287-95.

[17] Haas R, Resch G, Panzer C, Busch S, Ragwitz M, Held A. Efficiency and effectiveness of promotion systems for electricity generation from renewable energy sources Lessons from EU countries. Energy 2011; 36: 2186-93.

[18] Del Río P. The dynamic efficiency of feed-in tariffs: The impact of different design elements. Energy Policy 2012; 41: 139-51.

[19] Jenner S, Groba F, Indvik J. Assessing the strength and effectiveness of renewable electricity feed-in tariffs in European Union countries. Energy Policy 2013; 52:385-401.

[20] Pablo-Romero MP. Solar energy: Incentives to promote PV in EU27. AIMS Energy 2013; 1: 28-47.

[21] Campoccia A, Dusonchet L, Telaretti E, Zizzo G. An analysis of feed-in tariffs for solar PV in six representative countries of the European Union. Solar Energy 2014; 107: 530-42.

[22] Dusonchet L, Telaretti E. Comparative economic analysis of support policies for solar PV in the most representative EU countries. Renewable and Sustainable Energy Reviews 2015; 42: 986-98.

[23] Dong CG. Feed-in tariff vs. renewable portfolio standard: An empirical test of their relative effectiveness in promoting wind capacity development. Energy Policy 2012; 42: 476-85.

[24] Lantiainen S, Song N.. Review and comparative analysis of US and EU public policies promoting wood energy. In: Dell G, Egger C. editors. World sustainable energy days next 2014, Wiesbaden: Springer Fachmedien; 2015, pp. 89-94.

[25] Scarlat N, Dallemand JF, Monforti-Ferrario F, Banja M, Motola V. Renewable energy policy framework and bioenergy contribution in the European Union - An overview from National Renewable Energy Action Plans and Progress Reports. Renewable and Sustainable Energy Reviews 2015; 51: 969-85. 
[26] Resch G, Liebmann L, Ortner A, Busch S, Panzer C, Del Río P, et al. Design and impact of a harmonised policy for renewable Electricity in Europe. Final report of the beyond 2020 project; 2014. Available at: http://www.res-policy-beyond2020.eu/pdffinal/Final report beyond 2020 (beyond2020 - D7-4).pdf [accessed 10.11.16]

[27] Couture TD, Cory K, Kreycik C, Williams E. A policymaker's guide to feed-in tariff policy design. Technical report NREL/TP-6A2-44849. Colorado: National Renewable Energy Laboratory; 2010.

Available at: http://www.nrel.gov/docs/fy10osti/44849.pdf [accessed 10.11.16]

[28] RES Legal. Legal sources on renewable energy. Renewable energy policy database and support; 2016. Available at: www.res-legal.eu [accessed 10.11.16]

[29] IEA. International Energy Agency, Statistics; 2016. Available at: www.iea.org [accessed 10.11.16]

[30] European Commission. National action plans, energy, topics, renewable energy; 2016. Available at: https://ec.europa.eu/energy/en/topics/renewable-energy/national-action-plans [accessed 10.11.16]

[31] EurObserv'ER. Biogas barometer; 2012. Available at: http://www.eurobserv-er.org/biogasbarometer-2012/ [accessed 10.11.16]

[32] EurObserv'ER. RES policy reports, policy and statistics reports, progress report and country policy update report; 2015. http://www.eurobserv-er.org/eurobserver-policy-filesfor-all-eu-28-member-states/ [accessed 10.11.16]

[33] EurObserv'ER. RES barometers; 2016. Available at: http://www.eurobserv-er.org/ [accessed 10.11.16]

[34] CEER. Key support elements of RES in Europe: Moving towards market integration. CEER report C15-SDE-49-03. Brussels: Council of European Energy Regulators; 2016. Available at:

http://www.ceer.eu/portal/page/portal/EER HOME/EER PUBLICATIONS/CEER PAPERS/ Electricity/2016/C15 SDE-4903\%20CEER $\% 20$ report $\% 20$ on $\% 20 \mathrm{key} \% 20$ support $\% 20$ elements 26 January 2016.pdf [accessed 10.11.16]

[35] EurObserv'ER. Biogas barometer; 2010. Available at: http://www.eurobserv-er.org/biogasbarometer-2010/ [accessed 10.11.16]

[36] Fouquet D, Johansson TB. European renewable energy policy at crossroads - Focus on electricity support mechanisms. Energy Policy 2008; 36: 4079-92.

[37] Couture T, Gagnon Y. An analysis of feed-in tariff remuneration models: Implications for renewable energy investment. Energy Policy 2010; 38: 955-65.

[38] Held A, Ragwitz M, Gephart M, Kleßmann C, de Visser E. D5.2: Best practice design features for RES-E support schemes and best practice methodologies to determine remuneration levels. DiaCore project. Karlsruhe: Fraunhofer ISI; 2014. Available at: http://www.ecofys.com/files/files/diacore_best-practice-design-criteria-and-lcoe_2014_final.pdf [accessed 10.11.16]

[39] Hahn H, Jentsch A. Financing mechanisms for biogas projects in Central and Eastern Europe. IEE Project 'BiogasIN', project report D.6.4, WP 6. Kassel: Fraunhofer IWES; 2012. Available at: http://www.biogasin.org/files/pdf/reports/6.4. Biogas financing mechanisms/D.6.4bIWESEN.pdf [accessed 10.11.16] 
[40] European Commission. Guidelines on State aid for environmental protection and energy 2014-2020. Communication from the Commission. Official Journal of the European Union C 200; 2014: 1-55. Available at: http://eur-lex.europa.eu/legalcontent/EN/TXT/PDF/?uri=OJ:C:2014:200:FULL\&from=EN [accessed 10.11.16]

[41] Department of Communications, Climate Action and Environment. REFIT Schemes and Supports. New renewable electricity support schemes. Department of Communications, Climate Action and Environment, Government of Ireland. Available at: $\quad$ http://www.dccae.gov.ie/energy/en-ie/Renewable-Energy/Pages/New-RenewableElectricty-Support-Schemesn-Landing-Page.aspx [accessed 10.11.16]

[42] European Commission. Letter to the Member State - State aid SA.41998 (2015/N) Slovenia. European Commission, Brussels, 10.10.2016 COM(2016) 6592 final; 2016. Available at:http://ec.europa.eu/competition/state_aid/cases/258741/258741_1837726_154_2.pdf [accessed 10.11.16]

[43] Ragwitz M, Winkler J, Klessmann C, Gephart M, Resch G. Recent developments of feed-in systems in the EU - A Research Paper for the International Feed-in Cooperation. Ministry for the Environment, Nature Conservation and Nuclear Safety (BMU) of Germany; 2012. Available at:

http://www.feed-in-cooperation.org/wDefault_7/download-files/research/101105_feedin_evaluation_update-January-2012_draft_final_ISI.pdf [accessed 10.11.16]

[44] GSE. Statistical report 2011. Renewable energy power plants in Italy. Gestore dei Servizi Energetici; 2011. Available at:

http://www.gse.it/it/Dati e Bilanci/GSE_Documenti/ENG/Italy RES Stastistical Report 2011 WEB def 15-11-2012 tag.pdf [accessed 10.11.16]

[45] Maggoni L. Italian biomethane roadmap. The GreenGasGrids Project; 2014. Available at: http://www.greengasgrids.eu/fileadmin/greengas/media/Markets/Roadmaps/Italian_Biomethan e_Roadmap.pdf [accessed 10.11.16]

[46] Energy Industry Challenges. Renewable energy sources, Legislation, Denmark; 2016. Available at: http://www.i15.p.lodz.pl/strony/EIC/res/Denmark.html [accessed 10.11.16]

[47] European Commission. State aid: Commission approves amended Slovenian support scheme for renewable energy and high-efficiency cogeneration. European Commission - Press Release IP/16/3361, 10.10.2016. European Commission, Brussels; 2016. Available at: http://europa.eu/rapid/press-release_IP-16-3361_en.htm [accessed 10.11.16]

[48] Ministry of Economic Affairs of the Netherlands. Get to know the SDE+ 2012. NL Agency, Ministry of Economic Affairs of the Netherlands; 2012. Available at: http://english.rvo.nl/sites/default/files/2013/11/Brochure SDE English 2012.pdf [accessed 10.11.16]

[49] IRENA. Renewable energy tariff-based mechanisms. IRENA, Policy Advice and Capacity Building. International Renewable Energy Agency; 2012. Available at: http://www.irena.org/DocumentDownloads/events/2012/November/Tariff/1RabiaFerroukhi.pdf [accessed 10.11.16]

[50] Ragwitz M, Held A, Winkler J, Maurer C, Resch, G, Welisch M et al. Auctions for renewable energy in the European Union: Questions requiring further clarification. Study on behalf of Agora Energiewende; 2014. Available at: http://www.agoraenergiewende.de/fileadmin/Projekte/2014/Ausschreibungen-fuer-Erneuerbare-EnergienEU/Agora_Auctions-Paper_056_web.pdf [accessed 10.11.16] 
[51] Kitzing L, Mitchell C, Morthorst PE. Renewable energy policies in Europe: Converging or diverging? Energy Policy 2012; 51: 192-201.

[52] European Commisison. State of play on the sustainability of solid and gaseous biomass used for electricity, heating and cooling in the EU. Commission Staff Working Document. European Commission, Brussels, 28.7.2014 SWD(2014) 259 final; 2014. Available at: http://ec.europa.eu/energy/sites/ener/files/2014 biomass state of play .pdf [accessed 10.11.16]

[53] Couture TD, Jacobs D, Rickerson W, Healey V. The next generation of renewable electricity policy. NREL/TP-7A40-63149. Colorado: National Renewable Energy Laboratory; 2015. Available at: http://www.nrel.gov/docs/fy15osti/63149.pdf [accessed 10.11.16]

[54] EBA. France boosts biogas subsidies. European Biogas Association; 2016. Available at: http://european-biogas.eu/2015/08/12/france-boosts-biogas-subsidies/ [accessed 10.11.16]

[55] Thrän D, Hennig C, Rensberg N, Denysenko V, Fritsche UR, Eppler U. Country report Germany. IEA Bioenergy Task 37; 2015. Available at: http://www.iea-biogas.net/countryreports.html?file=files/daten-redaktion/download/publications/countryreports/2015/Germany_Country_Report_Berlin_10-2015.pdf [accessed 10.11.16]

[56] Lukehurst CT. Country report, U.K. IEA Bioenergy Task 37; 2015. Available at: http://www.iea-biogas.net/country-reports.html?file=files/datenredaktion/download/publications/countryreports/2015/United_Kingdom_Country_Report_Berlin_10-2014.pdf [accessed 10.11.16]

[57] Bourguignon D. Biomass for electricity and heating. Opportunities and challenges. European Parliament Research Service; 2015. Available at: http://www.europarl.europa.eu/RegData/etudes/BRIE/2015/568329/EPRS_BRI(2015)568329 _EN.pdf [accessed 10.11.16] 
Table 1

Electricity generated from biogas in the EU-28. Production and evolution.

\begin{tabular}{|c|c|c|c|c|c|c|}
\hline & \multicolumn{2}{|c|}{ Production (GWh) } & \multicolumn{2}{|c|}{ Growth $(2010-2013)$} & \multicolumn{2}{|c|}{ Ranking } \\
\hline & 2010 & 2013 & Rate & Absolute & 2013 & $\begin{array}{l}\text { Growth } \\
2010-13\end{array}$ \\
\hline AUSTRIA & 649 & 615 & -0.05 & -34.00 & 9 & 26 \\
\hline BELGIUM & 566 & 598 & 0.06 & 32.00 & 10 & 15 \\
\hline BULGARIA & 1.6 & 0.5 & -0.69 & -1.10 & 28 & 23 \\
\hline CROATIA & 30 & 63.2 & 1.11 & 33.20 & 20 & 14 \\
\hline CYPRUS & 35 & 52 & 0.49 & 17.00 & 23 & 19 \\
\hline CZECH REPUBLIC & 635 & 2294 & 2.61 & 1659.00 & 4 & 3 \\
\hline DENMARK & 357 & 257 & -0.28 & -100.00 & 11 & 28 \\
\hline ESTONIA & 10 & 21 & 1.10 & 11.00 & 25 & 20 \\
\hline FINLAND & 89 & 140 & 0.57 & 51.00 & 19 & 12 \\
\hline FRANCE & 1053 & 1521 & 0.44 & 468.00 & 5 & 5 \\
\hline GERMANY & 17430 & 29000 & 0.66 & 11570.00 & 1 & 1 \\
\hline GREECE & 190 & 216.4 & 0.14 & 26.40 & 15 & 17 \\
\hline HUNGARY & 118 & 242.8 & 1.06 & 124.80 & 13 & 10 \\
\hline ITALY & 2056 & 7448 & 2.62 & 5392.00 & 2 & 2 \\
\hline IRELAND & 206 & 200 & -0.03 & -6.00 & 17 & 24 \\
\hline LATVIA & 57 & 223 & 2.91 & 166.00 & 14 & 8 \\
\hline LITHUANIA & 31 & 59 & 0.90 & 28.00 & 21 & 16 \\
\hline LUXEMBURG & 55 & 55.3 & 0.01 & 0.30 & 22 & 22 \\
\hline MALTA & 0 & 3 & n.a. & 3.00 & 27 & 21 \\
\hline NETHERLANDS & 1028 & 966 & -0.06 & -62.00 & 6 & 27 \\
\hline PORTUGAL & 100 & 248 & 1.48 & 148.00 & 12 & 9 \\
\hline ROMANIA & 1 & 25.8 & 24.80 & 24.80 & 24 & 18 \\
\hline POLAND & 398 & 882.5 & 1.22 & 484.50 & 8 & 4 \\
\hline SLOVAKIA & 34 & 204 & 5.00 & 170.00 & 16 & 7 \\
\hline SLOVENIA & 97 & 141 & 0.45 & 44.00 & 18 & 13 \\
\hline SPAIN & 848 & 908 & 0.07 & 60.00 & 7 & 11 \\
\hline SWEDEN & 36 & 12 & -0.67 & -24.00 & 26 & 25 \\
\hline UNITED KINGDOM & 5735 & 5930.7 & 0.03 & 195.70 & 3 & 6 \\
\hline Total EU & 31860 & 52327.2 & 0.64 & 20467.20 & & \\
\hline
\end{tabular}

Source: Own elaboration from EurObserv'ER [5], IEA [29] and NREAPs [30]. 
Table 2

Electricity generated from biogas in the EU-28. Targets and level of compliance.

\begin{tabular}{|c|c|c|c|c|c|c|}
\hline & \multicolumn{3}{|c|}{ Target $(\mathrm{GWh})$} & \multicolumn{3}{|c|}{ Level of Compliance (\%) } \\
\hline & 2010 & 2015 & 2020 & $\begin{array}{c}2010 \\
\text { (with respect to } \\
\text { 2010) }\end{array}$ & $\begin{array}{c}2015 \\
\text { (with respect to } \\
\text { 2013) }\end{array}$ & $\begin{array}{c}2020 \\
\text { (with respect } \\
\text { to 2013) } \\
\end{array}$ \\
\hline AUSTRIA & 553 & 567 & 581 & 117.36 & 108.47 & 105.85 \\
\hline BELGIUM & 393.3 & 776.8 & 1439.1 & 143.91 & 76.98 & 41.55 \\
\hline BULGARIA & 2 & 269 & 357 & 80.00 & 0.19 & 0.14 \\
\hline CROATIA & 32.8 & 99 & 260 & 91.46 & 63.84 & 24.31 \\
\hline CYPRUS & 30 & 84 & 143 & 116.67 & 61.90 & 36.36 \\
\hline CZECH REPUBLIC & 624 & 1754 & 2871 & 101.76 & 130.79 & 79.90 \\
\hline DENMARK & 194 & 721 & 2493 & 184.02 & 35.64 & 10.31 \\
\hline ESTONIA & n.a. & n.a. & n.a. & n.a. & n.a. & n.a. \\
\hline FINLAND & 40 & 50 & 270 & 222.50 & 280.00 & 51.85 \\
\hline FRANCE & 935 & 2129 & 3701 & 112.62 & 71.44 & 41.10 \\
\hline GERMANY & 13829 & 18946 & 23438 & 126.04 & 153.07 & 123.73 \\
\hline GREECE & 181 & 431 & 895 & 104.97 & 50.21 & 24.18 \\
\hline HUNGARY & 85 & 262 & 636 & 138.82 & 92.67 & 38.18 \\
\hline ITALY & 2129 & 4074 & 6020 & 96.57 & 182.82 & 123.72 \\
\hline IRELAND & 320 & 320 & 319 & 64.38 & 62.50 & 62.70 \\
\hline LATVIA & 64 & 39 & n.a. & 89.06 & 571.79 & n.a. \\
\hline LITHUANIA & 50 & 228 & 413 & 62.00 & 25.88 & 14.29 \\
\hline LUXEMBURG & 44 & 123 & 144 & 125.00 & 44.96 & 38.40 \\
\hline MALTA & 8 & 7 & 85 & 0.00 & 37.78 & 3.51 \\
\hline NETHERLANDS & 872 & 2161 & 4664 & 117.89 & 44.70 & 20.71 \\
\hline PORTUGAL & 19 & 28 & 28 & 526.32 & 885.71 & 885.71 \\
\hline ROMANIA & 19 & 600 & 950 & 5.26 & 4.30 & 2.72 \\
\hline POLAND & 328 & 943 & 4018 & 121.34 & 93.58 & 21.96 \\
\hline SLOVAKIA & 70 & 624 & 860 & 48.57 & 32.69 & 23.72 \\
\hline SLOVENIA & 148 & 351 & 367 & 65.54 & 40.17 & 38.42 \\
\hline SPAIN & 799 & 1302 & 2617 & 106.13 & 69.74 & 34.70 \\
\hline SWEDEN & 53 & 53 & 53 & 67.92 & 22.64 & 22.64 \\
\hline UNITED KINGDOM & 6830 & 6300 & 5570 & 83.97 & 94.14 & 106.48 \\
\hline Total EU & 28652.78 & 43242.74 & 63192.6 & 111.19 & 121.01 & 82.81 \\
\hline
\end{tabular}

n.a.: not available.

Source: Own elaboration from EurObserv'ER [5], IEA [29] and NREAPs [30]. 


\section{Table 3}

Countries of the EU-28 that apply FIT policies for the promotion of biogas.

\begin{tabular}{|c|c|c|c|}
\hline Countries & System of progressive reduction & Duration & Determining factors of the prices \\
\hline AUSTRIA & Annual reduction determined by law & 15 years & $\begin{array}{l}\text { Different prices based on the capacity and } \\
\text { technology of the plant and origin of the } \\
\text { biogas (sewage gas, landfill gas) }\end{array}$ \\
\hline BULGARIA & $\begin{array}{l}\text { No, the quantity established in the } \\
\text { agreement remains }\end{array}$ & 15 years & $\begin{array}{l}\text { Depending on the plant capacity and on the } \\
\text { origin of the biogas (from plant and animal } \\
\text { waste, household waste, household } \\
\text { wastewater) }\end{array}$ \\
\hline
\end{tabular}

Biogas plants: $€$ ct $12.51-18.67$ per $\mathrm{kWh}$, depending on the capacity. A share of $30 \%$ must be deployed by pure agricultural substrates and animal manure

CHP-plants: the FIT is granted with a premium of €ct 2 per $\mathrm{kWh}$ if certain criteria are fulfilled

Biomethane: €ct $12.51-16.51$ per $\mathrm{kWh}$

Sewage plants: €ct 5.76 per $\mathrm{kWh}$

Landfill plants: $€ c t 4.80$ per $\mathrm{kWh}$

Power plants working with thermal gasification of biomass:

Capacity >5 MW: €ct 17.39 per kWh and if comb. cycle

used: €ct 19.17 per $\mathrm{kWh}$. If this also comes from biomass or bio-decomposing fractions from industrial and household $€ \mathrm{ct}$ 22.43 per $\mathrm{kWh}$

Capacity $\leq 5 \mathrm{MW}$ : €ct 17.91 per kWh. If comb. cycle used $€$ ct 19.92 per $\mathrm{kWh}$. If biomass also comes from agricultural waste and waste: $€ c t 19.84$ per $\mathrm{kWh}$. If this comes from industrial and household waste $€$ ct 20.76 per $\mathrm{kWh}$

\begin{tabular}{c|ll}
\hline CROATIA No & 14 years & $\begin{array}{l}\text { For biogas from agricultural crops and } \\
\text { organic residues, plant and animal origin, } \\
\text { biodegradable waste, landfill gas and sewer } \\
\text { gas, the tariff varies according to the plant's } \\
\text { capacity }\end{array}$ \\
\hline
\end{tabular}

$\begin{array}{ll}\text { FRANCE } & \text { The percentage of tariff subject to reduction } \\ \text { is } 50 \%\end{array}$

15 years

Depends on the capacity of the plants and the energy performance

Plants with a:

Capacity $\geq 300$ and $<400 \mathrm{~kW}$ : $€$ ct 19 per kWh

Capacity $\geq 400 \mathrm{~kW}$ and $<1 \mathrm{MW}$ : €ct 16.5 per kWh

Capacity $\geq 1 \mathrm{MW}$ and $<2 \mathrm{MW}$ : €ct 16 per kWh

Capacity $\geq 2 \mathrm{MW}$ and $<5 \mathrm{MW}$ : €ct 15 per kWh

Plants with a:

Capacity $\leq 150 \mathrm{~kW}$ : €ct 9.745 per kWh

Capacity $\geq 2$ MW: €ct 8.121 per kWh

Plants with an energy performance of at least $70 \%$ may have a bonus of $€$ ct 4 , also applied for plants using a share of $60 \%$ or higher of livestock manure

New plants will receive the FIT, applicable when they are put into operation and will

$\begin{array}{ll} & \text { be apply for the entire period. } \\ \text { GERMANY The annual reduction rate for landfill gas }\end{array}$ and sewage gas is $1.5 \%$

For other forms of biomass a quarterly $0.5 \%$ reduction is applied

20 years

According to plant size and fuel (biogas from biomass, landfill, sewage gas)

Biomass plants: €ct $5.83-27.73$ per kWh minus $€ c t 0.2$ per kWh

Landfill plants: $€$ ct $5.83-8.42$ per $\mathrm{kWh}$ minus $€$ ct 0.2 per kWh

Sewage plants: €ct $5.83-6.69$ per kWh minus €ct 0.2 per $\mathrm{kWh}$

Landfill plants $\leq 2 \mathrm{MW}$. €ct 11.4 or 13.1 per $\mathrm{kWh}$ with or without government support

Landfill plants $>2 \mathrm{MW}$. €ct 9.4 or 10.8 per $\mathrm{kWh}$ with or without government support

$\begin{array}{ll}\text { GREECE Not available } & 20 \text { years with } \\ \text { possibility of }\end{array}$ Varies according to the energy source (landfill, biogas from biomass) and the extension. generating capacity. It also varies based on the receipt of some additional aid.

without government support

Biomass plants > $3 \mathrm{MW}$. €ct 19 or 20.9 per $\mathrm{kWh}$ with or without government support 
Plants with a:

Capacity $\leq 20 \mathrm{MW}$ : €ct 12,10 or 4 per $\mathrm{kWh}$ in peak, valley No, adjusted annually to the rate of $\begin{aligned} & \text { Not greater than the } \\ & \text { term of amortization }\end{aligned}$ inflation, less $1 \%$ of the plant.

Depends on the capacity of the plant, with three different tariff rates depending on the time of day (peak, valley and deep-valley periods)

Reference prices vary for each technology (landfill gas, anaerobic digestion) depending on the size of the plant and whether it is a CHP plant

Guaranteed and maximum FIT fixed from a special mechanism based on tenders. They vary based on the size of the plant and the technology (landfill gas, anaerobic digestion or other biodegradable organic

waste or substrates)

LUXEMBOURG Percentage established annually by law

15 years

Depends on the nominal electricity capacity of the plant

Depends on the size of the plant and on the origin of the biogas (landfill, fermentation of solid municipal waste, sewage sludge from waste water treatment, waste water and waste from the agricultural and food industries).

The plants classified as small production units participate in a price fixing mechanism by means of tenders.

Adjusted to the evolution of the prices, except if the plant is involved in other support programs: in such case, reductions of $4 \%, 8 \%, 12 \%$ and $16 \%$
15 years
Depending on the capacity of the plant and the origin of the biogas (landfill gas or sewage gas, anaerobic digestion thermochemical conversion)
15 years or deep-valley period, respectively

Capacity $>20$ and $\leq 50 \mathrm{MW}$ : €ct 9,8 or 3 per kWh in peak, valley or deep-valley period, respectively.

Capacity $>50 \mathrm{MW}$ : €ct 7,5 or 5 per kWh in peak, valley or deep-valley period, respectively

Landfill plants: €ct 8.56 per kW

Anaerobic digestion plants:

CHP $\leq, 500 \mathrm{~kW}$ : €ct 15.7 per kWh

CHP > $500 \mathrm{~kW}$ : €ct 13.66 per kWh

Non-CHP $\leq 500 \mathrm{~kW}$ : €ct 11.55 per $\mathrm{kWh}$

Non-CHP $>500 \mathrm{~kW}$ : $€$ ct 10.5 per $\mathrm{kWh}$

Landfill plants $\leq 10 \mathrm{~kW}$ : €ct 11.1 per $\mathrm{kWh}$

Anaerobic digestion plants, biodegradable organic waste and substrates $\leq 10 \mathrm{~kW}$ : €ct 13.4 per $\mathrm{kWh}$

Plants with a:

Capacity $\leq 150 \mathrm{~kW}$ : €ct 14.7 per kWh

Capacity $>150 \mathrm{~kW}$ and $\leq 300 \mathrm{~kW}$ : €ct 13.7 per kWh

Capacity $>300 \mathrm{~kW}$ and $\leq 500 \mathrm{~kW}$ : €ct 12.7 per kWh

Capacity $>500 \mathrm{~kW}$ and $\leq 2500 \mathrm{~kW}$ : : €ct 11.7 per kWh

Landfill plants: €ct 10.2-10.4 per kWh

Sewage and other plants: $€$ ct $11.5-11.7$ per kWh

Landfill and sewage plants: $€$ ct 7.03 per $\mathrm{kWh}$
Anaerobic digestion plants
$\leq 250 \mathrm{~kW}: € c t 12.05$ per $\mathrm{kWh}$
$>250 \mathrm{~kW}$ and $\leq 500 \mathrm{~kW}: € c t 11$ per $\mathrm{kWh}$
$>500 \mathrm{~kW}$ and $\leq 750 \mathrm{~kW}: € c t 10.3$ per $\mathrm{kWh}$
$>750 \mathrm{~kW}: € c t 10.23$ per $\mathrm{kWh}$
Anaerobic digestion plants (biomethane obtained from
biogas) $\leq 1 \mathrm{MW}: € c t 10.75$ per kWh
Anaerobic digestion (bio-degradable waste): $€ c t 9.55$ per
$\mathrm{kWh}$


Biomass plants: $€$ ct $16.175-16.555$ per $\mathrm{kWh}$ minus $€ \mathrm{ct} 0.2$ per $\mathrm{kWh}$

The tariff level mainly depends on the plant

Landill plants: fct $7.442-9.933$ per kWh minus fet 0.2 per bize and the origin of the biogas (biomass,

waste, digester, or landfill).

It also varies based on the receipt of some

additional support.

$\mathrm{kWh}$

Biodegradable waste plant: €ct 13.923 per $\mathrm{kWh}$ minus $€ \mathrm{ct}$ 0.2 per $\mathrm{kWh}$

Digester plant: €ct $6.61-8.59$ per $\mathrm{kWh}$ minus €ct 0.2 per $\mathrm{kWh}$

Adjusted annually to the rate of inflation

Additionally, a degression contingent is

applied. The degression rates are adjusted

depending on the levels of deployment

under the FIT. The tariffs are reduced when

the deployment exceeds the caps set by the

20 years

Payment rates depend on the installed

Plants with a:

\section{KIN}

government.

Capacity $\leq 250 \mathrm{~kW}: € c t 8.83$ per kWh

Capacity $>250 \mathrm{~kW}$ and $\leq 500 \mathrm{~kW}$ : €ct 8.15 per kWh

Capacity $>500 \mathrm{~kW}$ : €ct 8.4 per kWh

Source: Own elaboration from RES-Legal [28], IEA [29] and EurObserv'ER [32-33]. 
Table 4

Countries of the EU-28 that apply the FIP system for the promotion of biogas.

\begin{tabular}{|c|c|c|c|c|}
\hline Countries & FIP system & Duration & Specificities & Amount for Biogas \\
\hline DENMARK & Fixed premium & $\begin{array}{c}\text { Several terms and } \\
\text { deadlines }\end{array}$ & Maximum and guaranteed bonus & $\begin{array}{l}\text { Electricity generated by biogas plants produced by using } \\
\text { biomass. Maximum subsidy: €ct } 11 \text { per } \mathrm{kWh} \text {. Additionally a } \\
\text { guaranteed premium of } € \text { ct. } 3 \text { and } € \text { ct. } 1 \text { per } \mathrm{kWh} \text { is received. The } \\
\text { first is reduced or increased each year if the price of natural gas } \\
\text { exceeds or falls below a basic level. The second is reduced } \\
\text { annually until } 2020 \text {, when it will disappear } \\
\text { Co-firing: Maximum subsidy: €ct } 6 \text { per } \mathrm{kWh} \text {. for the portion of } \\
\text { the electricity generated by biogas. Additionally, guaranteed } \\
\text { premiums of €ct. } 3 \text { and } € c t .1 \text { per } \mathrm{kWh} \text { is received }\end{array}$ \\
\hline FINLAND & Sliding premium & 12 years & $\begin{array}{l}\text { FIP equal to the difference between the fixed target price } \\
\text { and the reference market price. If the reference market } \\
\text { price is below } 30 € \text {, the FIP is equal to the fixed target } \\
\text { price minus } € 30 \\
\text { Limits for receiving FIP: } \\
\text { Capacity }>19 \text { MVA } \\
\text { Production }>\text { the amount in the decision } \\
\text { Price of electricity is negative }\end{array}$ & $\begin{array}{l}\text { The target price is } € \text { ct } 8.35 \text { per } \mathrm{kWh} \\
\text { Heat bonus: } € \text { ct } 5 \text { per } \mathrm{kWh} \text { on top of the target price }\end{array}$ \\
\hline GERMANY & Sliding premium & 20 years & $\begin{array}{l}\text { FIP equal to the difference between the fixed reference } \\
\text { value and average monthly specific market price. The } \\
\text { reference value will be zero if market price is negative } \\
\text { during } 6 \text { consecutive hours } \\
\text { Management premium, with premiums based on the } \\
\text { origin of biogas and depending on the capacity of the } \\
\text { plant size }\end{array}$ & $\begin{array}{l}\text { Biogas from biomass: } € \text { ct } 5.85-27.73 \text { per } \mathrm{kWh} \text { minus } € \text { ct } 0.2 \\
\text { per kWh } \\
\text { Landfill gas: } € \text { ct } 5.83-8.42 \text { per } \mathrm{kWh} \text { minus } € \text { ct } 0.2 \text { per } \mathrm{kWh} \\
\text { Sewage gas: } € 5.83-6.69 \text { per } \mathrm{kWh} \text { minus } € \text { ct } 0.2 \text { per } \mathrm{kWh}\end{array}$ \\
\hline ITALY & Fixed premium & 20 years & $\begin{array}{l}\text { FIP equal to tariff for given plant category plus other } \\
\text { support elements, minus hourly power market price for } \\
\text { given price zone }\end{array}$ & $\begin{array}{l}\text { Products of biological origin: } € c t 1.40-1.80 \text { per } \mathrm{kWh} \\
\text { Products of biological origin and non-sourced separated } \\
\text { waste: } € \text { ct } 1.78-2.36 \text { per } \mathrm{kWh} \\
\text { Waste for which the biodegradable part is determined as a } \\
\text { fixed amount: } € \text { ct } 2.16 \text { per kWh } \\
\text { These basic incentives may be increased with other support } \\
\text { elements. }\end{array}$ \\
\hline NETHERLANDS & Sliding premium & 12 years & $\begin{array}{l}\text { Premiums vary in each of the tender stages (increases as } \\
\text { the stages advance), and also differ according to the } \\
\text { technology or origin of biogas and the plant size }\end{array}$ & $\begin{array}{l}\text { Cofermentation of animal waste: From } € \text { ct } 7 \text { per } \mathrm{kWh} \text { (stage } 1 \text { ) } \\
\text { to } € \text { ct. } 11.3 \text { per kWh (stages } 5-6 \text { ). } \\
\text { Fermentation of other substances: From } € c t 7 \text { per kWh (stage } 1 \text { ) } \\
\text { to } € \text { ct. } 9.5 \text { per kWh (stages } 4-6 \text { ). } \\
\text { Fermentation of animal waste }>\mathbf{9 5 \%} \text { : } € \text { ct. } 4 \text { per } \mathrm{kWh} \text { - } \\
\text { Sewage gas: } € c t 3.3 \text { per kWh }\end{array}$ \\
\hline SLOVENIA & Fixed premium & 12 years & $\begin{array}{l}\text { Recently, operators above } 500 \mathrm{~kW} \text { systems will offer the } \\
\text { produced power on the market and get a premium on top } \\
\text { of the market price }\end{array}$ & There are currently no price lists \\
\hline
\end{tabular}

Source: Own elaboration from RES-Legal [28], EurObserv'ER [32-33] and CEER report [34]. 
Table 5

Mechanisms of support for biogas in the EU-28.

\begin{tabular}{|c|c|c|c|c|c|}
\hline Countries & $\begin{array}{c}\text { Feed-in } \\
\text { tariffs }\end{array}$ & $\begin{array}{c}\text { Premium } \\
\text { tariffs }\end{array}$ & Tenders & $\begin{array}{c}\text { Compliance of } \\
\text { 2020 target } \\
\text { (\% respect to 2013) } \\
\end{array}$ & 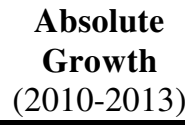 \\
\hline AUSTRIA & $\checkmark$ & & & 105.85 & -34.00 \\
\hline BELGIUM & & & & 41.55 & 32.00 \\
\hline BULGARIA & $\checkmark$ & & & 0.14 & -1.10 \\
\hline CROATIA & $\checkmark$ & & & 24.31 & 33.20 \\
\hline CYPRUS & & & & 36.36 & 17.00 \\
\hline CZECH REPUBLIC & & & & 79.90 & 1659.00 \\
\hline DENMARK & & $\checkmark$ & & 10.31 & -100.00 \\
\hline ESTONIA & & & & n.a. & 11.00 \\
\hline FINLAND & & $\checkmark$ & & 51.85 & 51.00 \\
\hline FRANCE & $\checkmark$ & & & 41.10 & 468.00 \\
\hline GERMANY & $\checkmark$ & $\checkmark$ & & 123.73 & 11570.00 \\
\hline GREECE & $\checkmark$ & & & 24.18 & 26.40 \\
\hline HUNGARY & $\checkmark$ & & & 38.18 & 124.80 \\
\hline IRELAND & $\checkmark$ & & & 62.70 & -6.00 \\
\hline ITALY & & $\checkmark$ & $\checkmark$ & 123.72 & 5392.00 \\
\hline LATVIA & & & & n.a. & 166.00 \\
\hline LITHUANIA & $\checkmark$ & & & 14.29 & 28.00 \\
\hline LUXEMBURG & $\checkmark$ & & & 38.40 & 0.30 \\
\hline MALTA & & & & 3.51 & 3.00 \\
\hline NETHERLANDS & & $\checkmark$ & & 20.71 & -62.00 \\
\hline POLAND & & & & 21.96 & 484.50 \\
\hline PORTUGAL & $\checkmark$ & & & 885.71 & 148.00 \\
\hline ROMANIA & & & & 2.72 & 24.80 \\
\hline SLOVAKIA & $\checkmark$ & & & 23.72 & 170.00 \\
\hline SLOVENIA & $\checkmark$ & $\checkmark$ & & 38.42 & 44.00 \\
\hline SPAIN & & & & 34.70 & 60.00 \\
\hline SWEDEN & & & & 22.64 & -24.00 \\
\hline UNITED KINGDOM & $\checkmark$ & & & 106.48 & 195.70 \\
\hline
\end{tabular}

Source: Own elaboration from RES-Legal [28], IEA [29] EurObserv'ER [32-33] and CEER report [34]. 


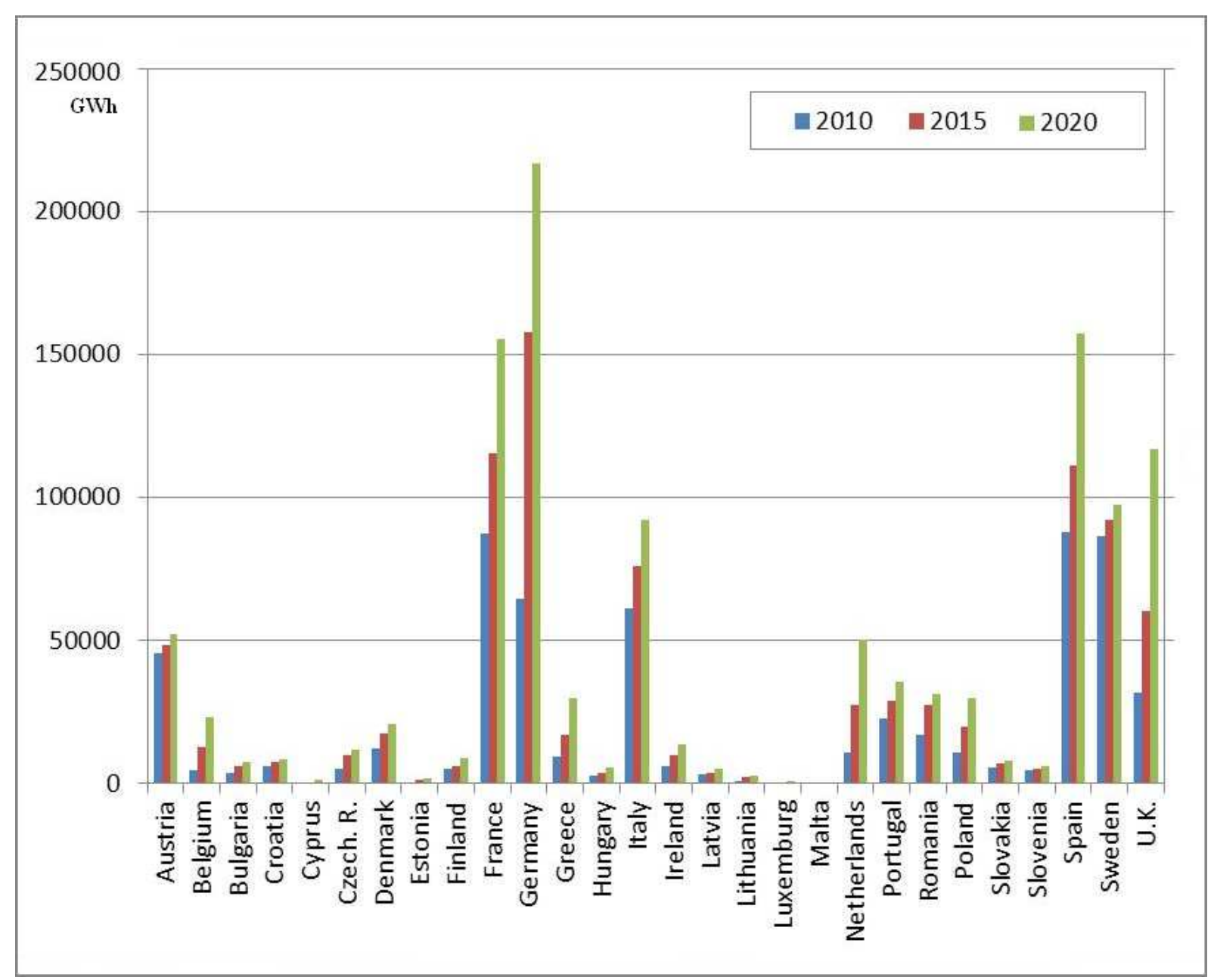

Fig. 1. Electricity production targets with renewable energy sources in each EU country $(\mathrm{GWh})$. Source: Own elaboration from NREAPs [30]. 


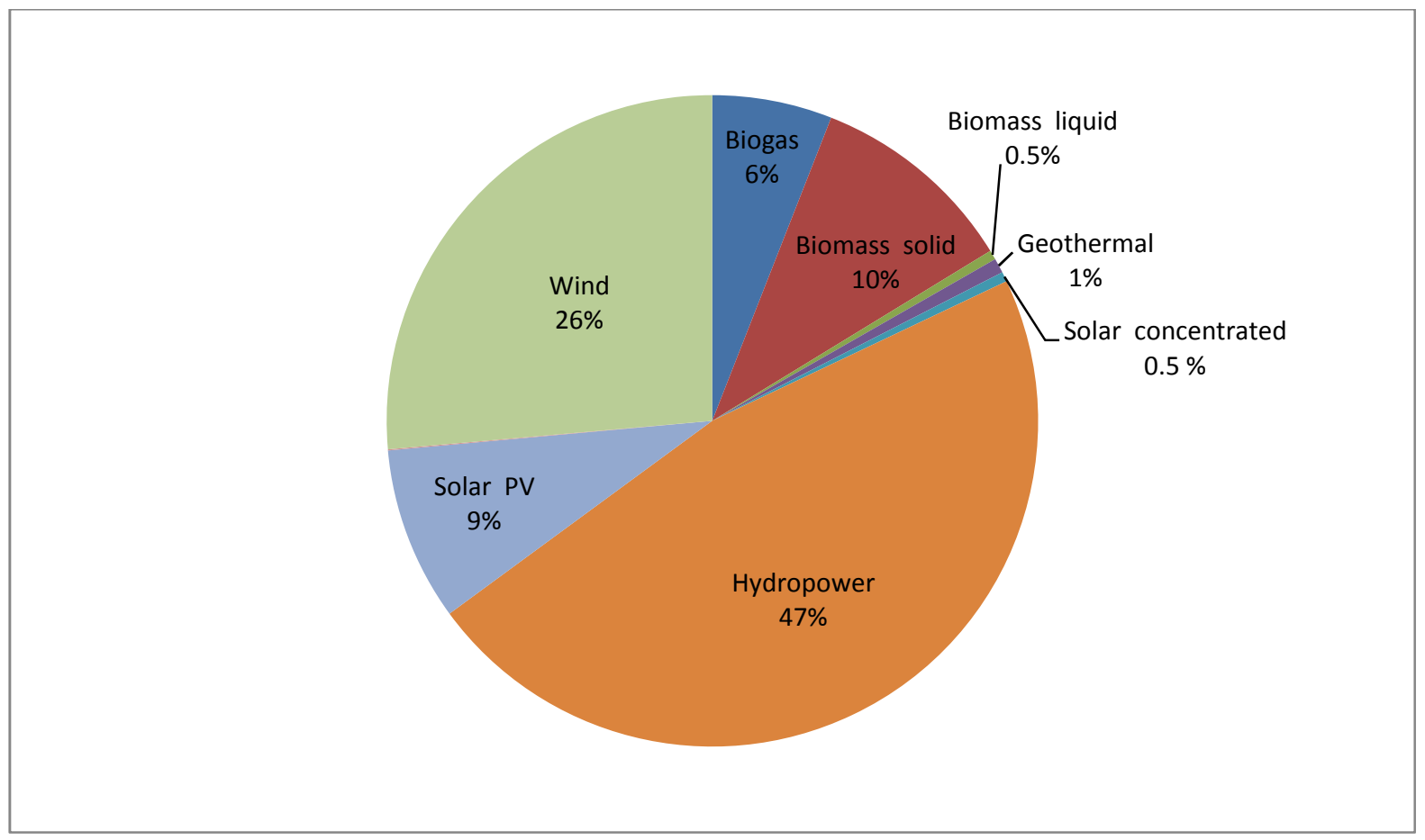

Fig. 2. Contribution of each renewable energy to the production of electricity in the EU-28 (2012). Source: Own elaboration from NREAPs [30]. 


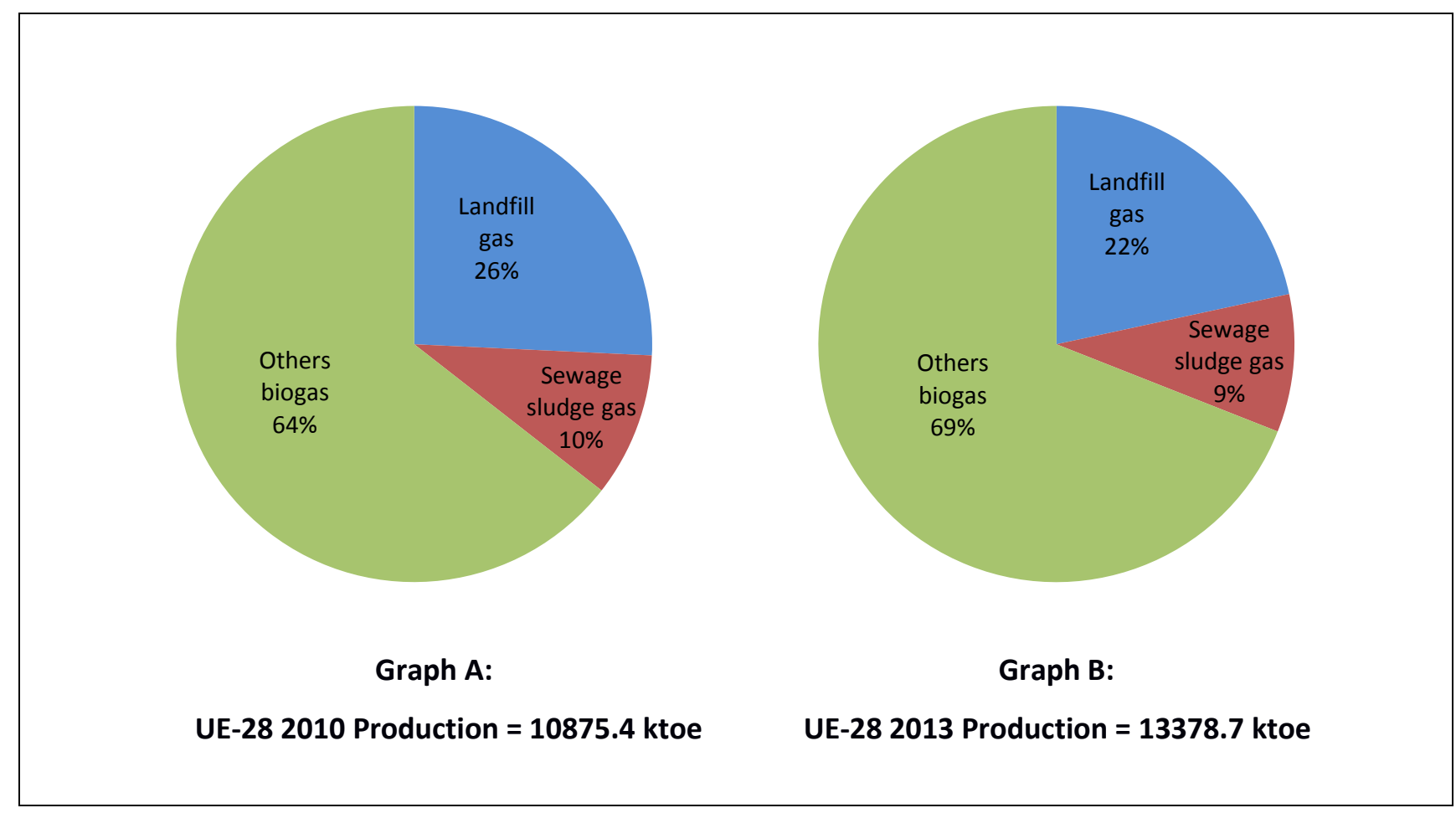

Fig. 3. Primary energy production of biogas in the EU-28.

Source: Own elaboration from EurObserv'ER [5, 31]. 


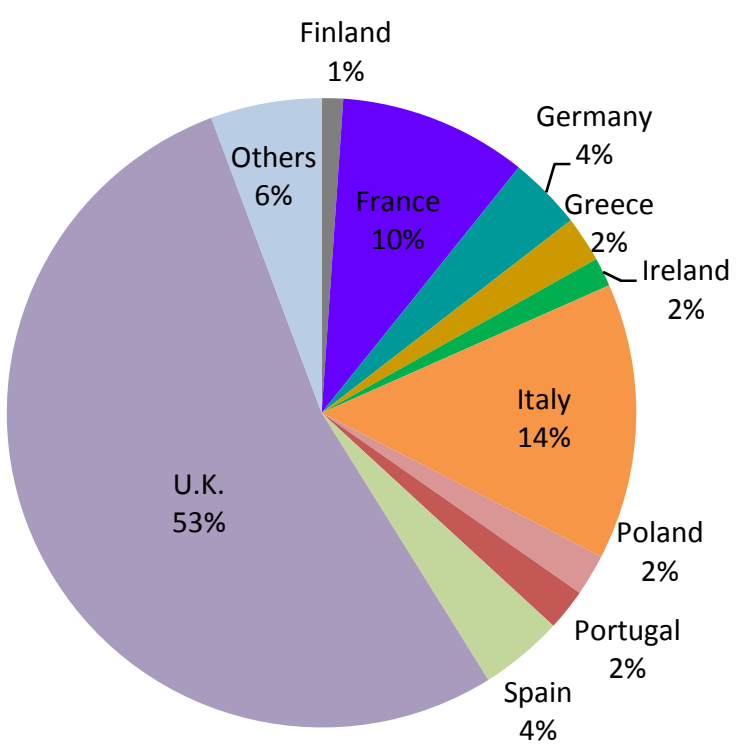

Graph A: Landfill gas

EU-28 2013 Production = 2892.3 ktoe

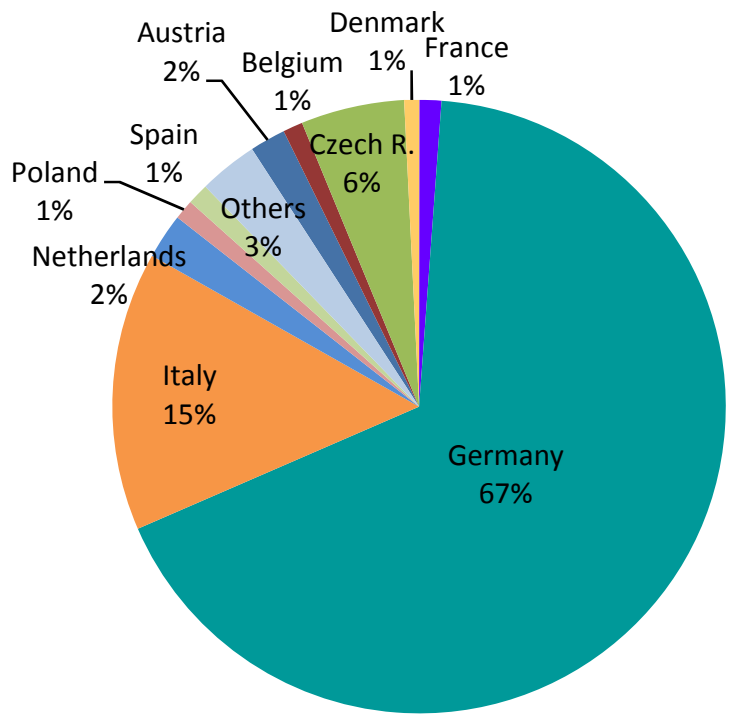

Graph C: Other biogas

EU-28 2013 Production = 9232.7 ktoe

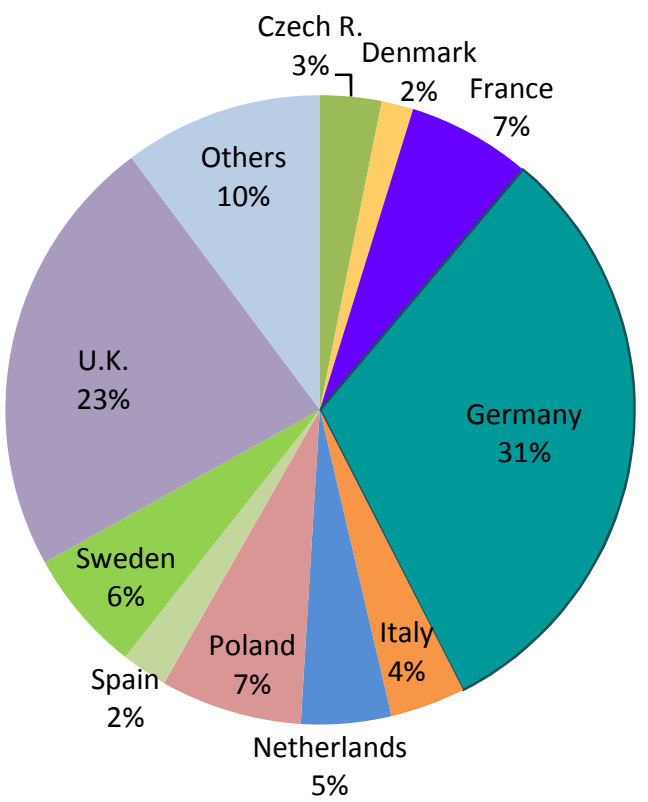

Graph B: Sewage sludge gas

EU-28 2013 Production = 1253.6 ktoe

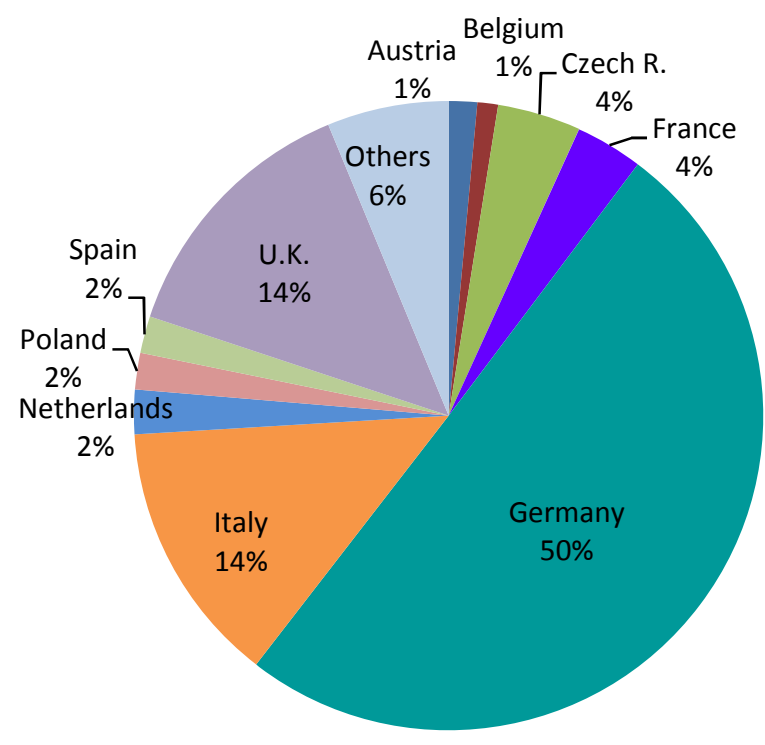

Graph D: Total biogas

EU-28 2013 Production $=13378.7$ ktoe

Fig. 4. Primary energy production of biogas in the EU-28.

Source: Own elaboration from EurObserv'ER [5]. 


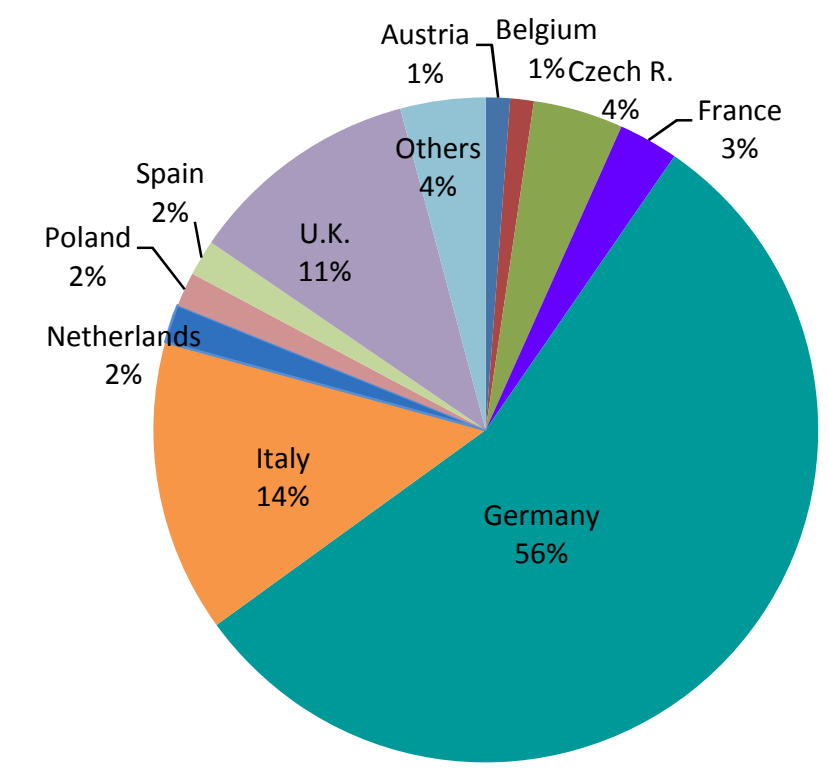

Graph A:

EU-28 2013 Production $=52327.2 \mathrm{GWh}$

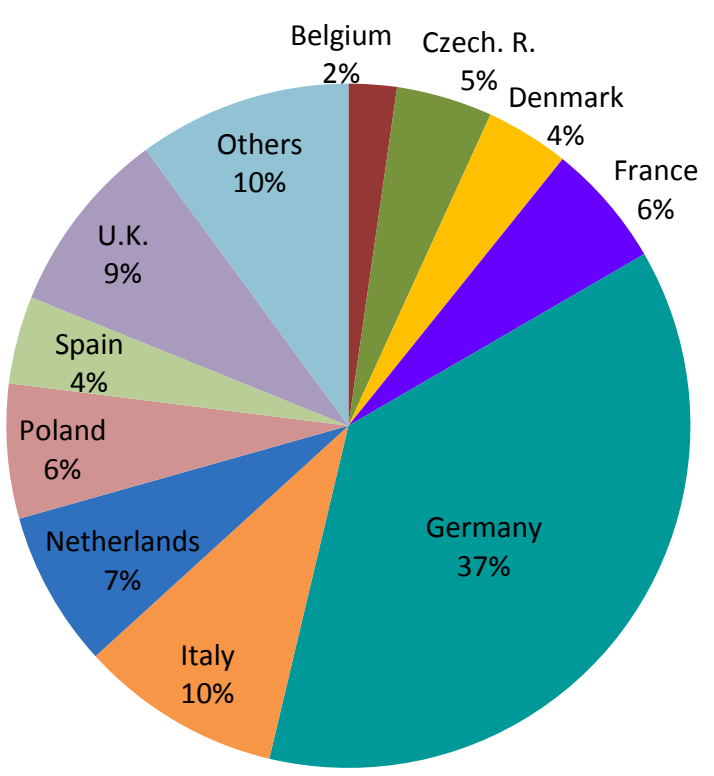

Graph B:

EU-28 2020 Target $=63192.6 \mathrm{GWh}$

Fig. 5. Electricity generated from biogas in the EU-28, by country, in 2013 and country percentage values of EU-28 Targets for 2020.

Source: Own elaboration from EurObserv'ER [5] and NREAPs [30]. 


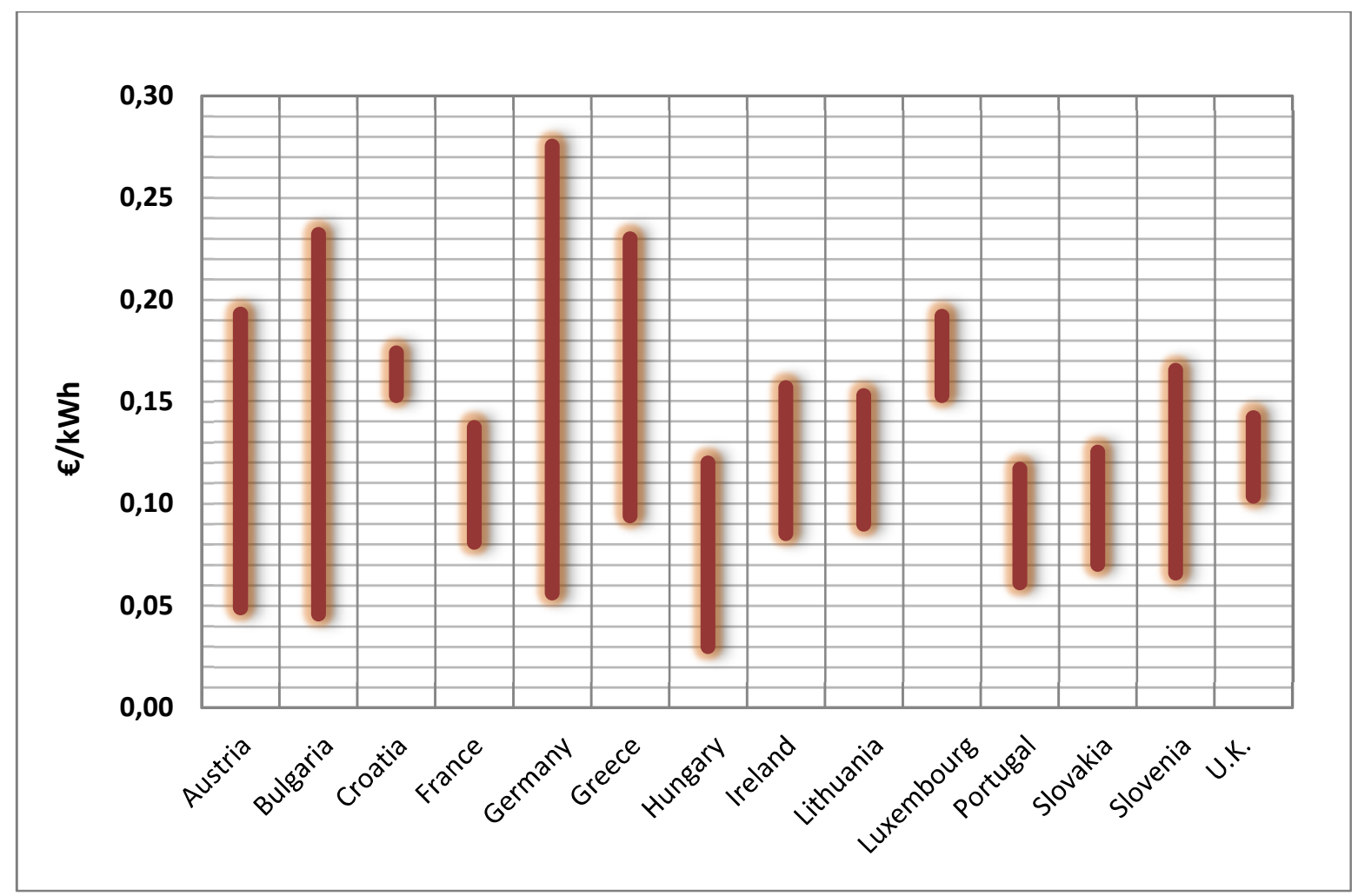

Fig. 6. Extent of feed-in tariffs.

Source: Own elaboration from RES-Legal [28], IEA [29] and EurObserv'ER [32-33]. 


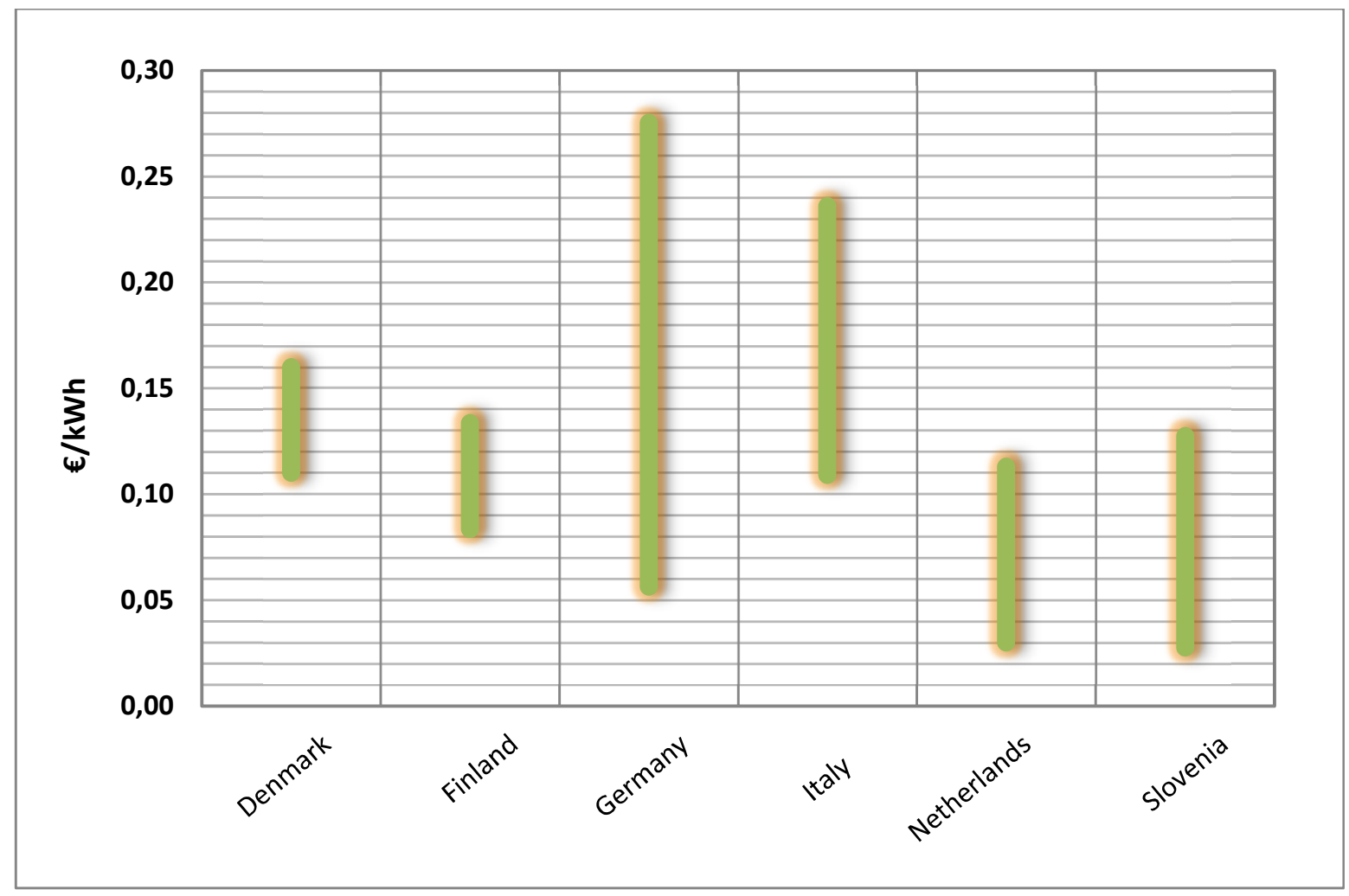

Fig. 7. Quantities of premium tariffs.

Source: Own elaboration from RES-Legal [28], EurObserv'ER [32-33] and CEER report [34]. 